(C) 2021, The Authors. Published by Elsevier Inc. and Fass Inc. on behalf of the American Dairy Science Association ${ }^{\circledR}$. This is an open access article under the CC BY-NC-ND license (http://creativecommons.org/licenses/by-nc-nd/4.0/).

\title{
Six catalytic activities and cytotoxicity of immunoglobulin G and secretory immunoglobulin A from human milk
}

\author{
Georgy A. Nevinsky, ${ }^{1 *}$ ๑ Ol'ga D. Zakharova, ${ }^{1}$ 이 Ivan Yu. Kompaneets, ${ }^{1}$ Anna M. Timofeeva, ${ }^{1}{ }^{\circ}$ \\ Pavel S. Dmitrenok, ${ }^{2}$ (๑) and Natalia I. Menzorova ${ }^{2}$ () \\ ${ }^{1}$ Institute of Chemical Biology and Fundamental Medicine, Siberian Branch of the Russian Academy of Sciences, 8 Lavrentiev Ave., \\ Novosibirsk 630090, Russia \\ ${ }^{2}$ G. B. Elyakov Pacific Institute of Bioorganic Chemistry, Far Eastern Branch of the Russian Academy of Sciences, 159 Pr. 100 let Vladivostoku, \\ Vladivostok 690022, Russia
}

\section{ABSTRACT}

In the milk of healthy women, antibodies were found with different catalytic activities (abzymes), which are absent in the sera of other healthy people. Moreover, it was previously shown that DNase antibodies-abzymes of patients with autoimmune diseases are cytotoxic to cancer cells. In this work, it was first shown that IgG and secretory $\operatorname{IgA}(\operatorname{sg} \mathrm{A})$ do not possess embryotoxicity; they practically do not affect the development of fertilized eggs of sea urchins but demonstrate sperm toxicity. After addition to the eggs of sperm preincubated with $\operatorname{IgG}$ and $\operatorname{sIg} A$, the number of unfertilized eggs was increased, in the case of sIgA 1.6-fold higher than that for IgG. The suppression of the growth of MCF-7 breast cancer cells by $\operatorname{sIgA}$ was 2.2 times more effective than with IgG antibodies. The relative enzymatic activity of milk sIgA was higher than IgG (-fold): 1.9 (DNase), 4.6 (amylase), 1.7 (peroxidase), 1.3 (protease), 3.7 [hydrolysis of poly $(\mathrm{C})], 3.3$ [hydrolysis of poly(U)], and 1.7 (oxidation of $3,3^{\prime}$-diaminobenzidine). One of the possible reasons for the observed difference between sIgA and IgG could be that all 6 catalytic activities of sIgA were, on average, 2.6 times higher than that for IgG. Correlation coefficients between all the relative 6 enzymatic activities of $\operatorname{IgG}$ and $\operatorname{sIg} \mathrm{A}$ and their toxicity to sea urchin sperm and to cancer cells were calculated. Maximum correlation coefficients were observed for DNase $(+0.71)$, protease $(+0.64)$ activities for $\operatorname{sIgA}$, as well as protease $(+0.59)$ and RNase $(+0.77)$ of $\operatorname{IgG}$ with their toxicity toward sperm. The correlation coefficients were also high between peroxidase activity $(+0.85)$ of $\operatorname{sIgA}$ and poly(U) hydrolysis by $\operatorname{IgG}(+0.58)$ with their suppression of tumor cell growth. It has been suggested that the catalytic activities of abzymes may

Received November 11, 2020

Accepted January 11, 2021.

*Corresponding author: nevinsky@niboch.nsc.ru be important in the manifestation of their sperm toxicity and inhibition of cancer cell growth.

Key words: human milk IgG and sIgA abzymes, embryotoxicity, sperm toxicity, cytotoxicity toward tumor cells

\section{INTRODUCTION}

For breast-fed newborns, breast milk is a source of different substances [e.g., nucleic acids, proteins, peptides, hormones, antibodies (Abs), and so on] and other bioactive components promoting infant growth and protection from viral and bacterial infections (Jensen et al., 1995; Lönnerdal, 2003). The functions of many breast milk components and Abs in terms of newborn nutrition and protection may be very different compared with those for blood sera and other biological fluids of healthy adults (Jensen et al., 1995; Lönnerdal, 2003).

Human milk contains secretory $\operatorname{IgA}(\mathbf{s I g A}), \operatorname{Ig} \mathrm{A}$, $\operatorname{IgG}$, and IgM, of which sIgA are the major component (>85-90\%), while the content of IgG does not exceed $5 \%$ (Mestecky et al., 1986; Hanson et al., 1994). The IgA are produced by B-lymphocytes of the mammary gland immune system (Hanson et al., 1994); they are produced in mothers' Peyer's patch lymphoid cells and then migrate to mucosal sites generating local $\mathrm{SIgA}$. The source of IgG in milk is still debated; they may be partially produced locally by the mammary gland-specific cells and partially transferred from lactating women's blood circulation system (Mestecky et al., 1986). During the first 5 to $7 \mathrm{mo}$ of life, the infant immune system is not operational yet; all mucous surfaces of infants lack Abs (Hanson et al., 1979). However, breast-fed infants are well protected by antibodies obtained via intake of mother's milk (passive immunity). The Abs against bacterial components, viruses, and so on cover the baby's mucous membranes (Hanson et al., 1979). In breast milk, sIgA remain at least 7.5 mo after nascence and play an important role in providing the passive 
humoral response (Rechtman et al., 2002). The IgG of breast milk enters the bloodstream of babies through the epithelium of their intestines.

It was shown that the blood sera of patients with autoimmune diseases (AID) contain various auto-Abs with different catalytic activities (abzymes, ABZ), which can be immunoglobulins directed to various antigens with altered conformations (compounds mimicking transition states of chemical reactions) or secondary anti-idiotypic auto-Abs against the active sites of enzymes (for reviews, see Keinan, 2005; Nevinsky, and Buneva, 2003, 2005; Nevinsky, 2010, 2011, 2016, 2017). It was shown that the existence of ABZ in the blood sera is a clear and statistically reliable sign of the occurrence of autoimmune processes in humans. Abzymes were not found in healthy people and patients in which diseases occur without significant violations of the immune status. Because of the absence of manifested immunization, the existence of natural ABZ in healthy donors without any immune pathologies has long been considered impossible. In healthy people, except for pregnant and lactating women, ABZ are absent. Pregnant and lactating women are not considered sick, but ABZ are present in their blood and milk. Consequently, a particular group of people to study is healthy pregnant and lactating women (Buneva et al., 2003; Nevinsky, 2010).

It was unpredictable that small subfractions of polyclonal sIgA and IgG from breast milk and blood split DNAs, RNAs, micro-RNAs (Buneva et al., 1994, 2003; Kompaneets et al., 2020a,b), different ribo- and deoxyribonucleotides; demonstrate phosphatase activity (Semenov et al., 2004); and hydrolyze polysaccharides (Savel'ev et al., 2001) and proteins (Odintsova et al., 2005). Therefore, the question arises of why ABZ are found in the blood of healthy pregnant women, as well as in sera and milk of lactating women.

During pregnancy and with the onset of lactation, women are characterized by an immune status similar to that of AID patients (Dayan and Daniels, 1996; Amino et al., 1986, 1999). Different types of AID originate from defects of hematopoietic stem cell differentiation (Watanabe-Fukunaga et al., 1992; Andryushkova et al., 2006, 2007, 2009; Doronin et al., 2016; Aulova et al., 2017, 2018, 2019). In addition, using autoimmune systemic lupus erythematosus (SLE) mouse models, it was shown that these changes in stem cell differentiation in typical AID and healthy lactating mice are very similar (Andryushkova et al., 2006, 2007, 2009). However, the changes in the differentiation profile of hematopoietic stem cells in lactating mice were temporary, and 2 to 3 mo after birth, they returned to baseline, when in spontaneously diseased SLE mice, the changes were permanent. It seems very important that pregnant and lactating women may be directly immunized through a particular response of their immune systems to different viral, bacterial, or food origin compounds, which can efficiently stimulate the production of different Abs (Fey et al., 1973). Immunization of experimental animals by direct injection of various antigens (mainly proteins) into the bloodstream or by oral administration no more than 0.7 to 3 mo before delivery leads to the production of anti-protein Abs, which then may be detected in the milk at high concentrations (Fey et al., 1973). Production of milk Abs starting several months after the immunization supports the existence of a specific "immuno-memory" in pregnant women. In addition, several hidden autoimmunization processes take place in the mother's body. It turned out that during pregnancy, the blood of women (as well as the blood of patients with AID) contains DNA in high concentrations (Mohan et al., 1993), as well as fetal cells in low concentrations (Kazakov et al., 1995).

During pregnancy, the possibility of manifestation of signs of various kinds of AID was noted in previously healthy women. Interestingly, a sharp exacerbation of specific autoimmune reactions ("autoimmune shock") can occur immediately after childbirth (Amino et al., 1999).

It has been shown that the dynamics of changes in the DNase activity of ABZ in the blood of women during pregnancy is individual for each woman (Buneva et al., 2003); the activity increases mostly in the first or third trimester (or both) of pregnancy. The relative nuclease activities of blood IgG increase significantly after childbirth immediately after the onset of lactation, but the exceptionally high activity of $\operatorname{sg} \mathrm{A}$ and $\operatorname{IgG}$ was found in the milk. The data considered above unambiguously indicate that during pregnancy and immediately after childbirth, women tend to develop various autoimmune processes similar to those for patients with AID.

Most of the ABZ from sera of patients with AID usually catalyze the hydrolysis of various substrates (DNA, RNA, proteins, oligosaccharides, and so on; for reviews, see Keinan, 2005; Nevinsky, and Buneva, 2003, 2005; Nevinsky, 2010, 2011, 2016, 2017). Abzymes hydrolyzing the same substrates have been found in human milk. However, human milk has proven to be an amazing source of ABZ that are not found in AID patients' blood. The first examples of ABZ catalyzing not hydrolytic but synthetic reactions were sIgA from breast milk phosphorylating 15 different milk proteins (Kit et al., 1996; Nevinsky et al., 1998). Then, milk ABZ phosphorylating unique lipids (Gorbunov et al., 2000,2005 ) and unusual polysaccharides (Karataeva et al., 2006a,b) were revealed. Thus, it should be em- 
phasized that human milk contains a large set of very different ABZ, including those that are not present in the blood of patients with various types of AID.

The DNA-hydrolyzing ABZ from the blood of patients with SLE, lymphoproliferative diseases (Kozyr et al., 1998), multiple sclerosis (Nevinsky and Buneva. 2003), and Bence Jones proteins from the urine of myeloma patients (Sinohara and Matsuura, 2000) are cytotoxic; they penetrate into cell nuclei, hydrolyze chromatin DNA, and induce apoptosis of cancer cells. Currently, no data are available on the cytotoxicity of IgG and sIgA of human milk and the possible relationship of their catalytic functions with their effect on different cells.

In this work, for the first time, an analysis of the cytotoxicity of auto-ABZ of human milk against eggs and sperm of the sea urchins, as well as human cancer cells, was carried out. The correlation coefficients (r) of the relative toxicity indexes for milk sIgA and $\operatorname{Ig} G$ with their 6 catalytic activities were estimated.

\section{MATERIALS AND METHODS}

\section{Chemicals and Donors}

Most chemicals used for this study were provided by Sigma. The Superdex 200 HR 10/30 column, Protein G-Sepharose, and Protein A-Sepharose were obtained from GE Healthcare.

The milk sampling protocol was conformed (local human ethics committee of Novosibirsk State Medical University, Novosibirsk, Russia; protocol number 72M). The ethics committee specifically approved this study in conformity with Helsinki ethics committee guidelines. All mothers gave written consent and donated their milk for scientific purposes. The mothers have no history of respiratory, autoimmune, gastrointestinal, rheumatologic, cardiovascular, or other system pathologies.

\section{Purification and Analysis of Antibodies}

The IgG and sIgA were obtained from 7 milk samples as in Kit et al. (1996), Nevinsky et al. (1998), Gorbunov et al. (2000, 2005), and Karataeva et al. (2006a,b). The milk of clinically healthy mothers living in the Novosibirsk region of Russia (100 mL at one time; $19-36$ yr old) was collected 1 to 3.5 wk after the beginning of lactation. Milk was obtained using the sterile standard devices existing for removing the mother's milk excess. One to three hours after collection, milk samples were cooled to $4^{\circ} \mathrm{C}$ and centrifuged for 20 min at $22^{\circ} \mathrm{C}$ using an Eppendorf centrifuge (14,000 rpm). To obtain milk plasma, lipid and cell phases were removed. There was no essential variation in the relative content of $\operatorname{IgG}$ and sIgA and their enzymatic activities within the sampling period of 1 to $4 \mathrm{wk}$ after the beginning of lactation (Kompaneets et al., 2020a,b).

To obtain IgG, the milk plasma (milk containing no cells; $10 \mathrm{~mL}$ ) samples were loaded on a column with Protein G-Sepharose equilibrated $20 \mathrm{~m} M$ Tris-HCl buffer ( $\mathrm{pH} 7.5$ ) containing $0.15 \mathrm{M} \mathrm{NaCl}$ (buffer A). The flow-through sIgA containing fractions were applied on the Protein A-Sepharose column equilibrated with the same buffer A. All nonspecifically bound proteins were eluted separately from Protein G-Sepharose and Protein A-Sepharose first with buffer A up to zero optical density $\left(\mathrm{A}_{280}\right)$, and then this buffer was supplemented with $0.3 \mathrm{M} \mathrm{NaCl}$ and $1 \%$ Triton X-100, and again using buffer $\mathrm{A}$ to zero optical density $\left(\mathrm{A}_{280}\right)$. The sIgA and IgG were specifically eluted from corresponding affinity sorbents with acidic $0.1 M$ glycine- $\mathrm{HCl}$ ( $\mathrm{pH} 2.6$ ). The fractions were immediately neutralized by $1 \mathrm{M}$ Tris- $\mathrm{HCl}(\mathrm{pH} 8.5)$ and then dialyzed against $20 \mathrm{mM}$ Tris-HCl (pH 7.5).

For additional purification, $\operatorname{IgG}$ and sIgA preparations $(1-2.5 \mathrm{mg} / \mathrm{mL}, 0.5-1.0 \mathrm{~mL})$ were preincubated in $20 \mathrm{~m} M$ acidic glycine buffer $(\mathrm{pH} 2.6)$ containing $0.25 \mathrm{M} \mathrm{NaCl}$ at $22^{\circ} \mathrm{C}$ for $20 \mathrm{~min}$ and then subjected to fast-performance liquid chromatography (FPLC) gel filtration on a Superdex 200 HR 10/30 according to Kit et al. (1996), Nevinsky et al. (1998), Gorbunov et al. (2000, 2005), and Karataeva et al. (2006a,b). Collected fractions of $\operatorname{sIg} \mathrm{A}$ and $\operatorname{IgG}$ were immediately neutralized with Tris- $\mathrm{HCl}(\mathrm{pH} 8.5)$ and dialyzed against $20 \mathrm{mM}$ Tris- $\mathrm{HCl}(\mathrm{pH}$ 7.5). For refolding of Abs after acidic treatment, different activities of Abs were measured after 1.5 to 2.5 wk of preparation storage in this buffer at $4^{\circ} \mathrm{C}$.

DNase Activity Assay. The DNA-hydrolyzing activity was analyzed using supercoiled (sc) DNA as described earlier for analysis of DNase I, DNase II (Love and Hewitt, 1979; Suck, 1994), and human serum catalytic Abs (Buneva et al., 2003). The reaction mixtures $(20 \mu \mathrm{L})$ containing $20 \mu \mathrm{g} / \mathrm{mL}$ scDNA pBluescript (molecular mass 2,086,535 g/mol), $10 \mathrm{mM}$ $\mathrm{MgCl}_{2}, 50 \mathrm{mM}$ Tris-HCl (pH 7.5) and 0.1 to $0.26 \mu M$ IgG or sIgA (corresponding to linear parts of reaction rate dependences on Abs concentration, which were different for every individual preparation) were incubated at $37^{\circ} \mathrm{C}$ for 0.5 to $2.0 \mathrm{~h}$ (corresponding to linear parts of reaction product formation dependences upon time). The cleavage products were analyzed by agarose gel (1\%) electrophoresis. The images of ethidium bromidestained gels were captured on a Sony DSC-F717 camera (Sony Centre), and a relative amount of DNA in different bands was analyzed using ImageQuant v5.2 
(Molecular Dynamics). The activities of IgG and sIgA preparations were determined as a decrease in the percentage of scDNA converted from the initial scDNA form to the relaxed form, corrected for the distribution of DNA between these bands in control (incubation of pBluescript DNA in the absence of Abs). For each IgG preparation, dependence of the rate on its concentration and time of incubation were obtained. Finally, all measurements (initial rates of the reaction) were estimated using the linear regions of $\operatorname{IgG}$ concentrations and the time courses (15-40\% of scDNA hydrolysis). A complete transition of the supercoiled plasmid to the nicked form was taken for $100 \%$ activity. If the activity was low $(<5-10 \%$ of scDNA disappearance), the incubation was prolonged to 1.5 to $2.0 \mathrm{~h}$, depending on the sample. If the degradation of scDNA after $1 \mathrm{~h}$ of incubation exceeded $50 \%$, the Abs concentration was lowered 2- to 5-fold, depending on the sample. This approach allowed normalization of Abs relative activity estimated using different time of incubation and various antibody concentrations to the same standard condition; percent of scDNA hydrolysis in the presence of $0.26 \mu M \operatorname{IgG}$ or sIgA, $1 \mathrm{~h}$.

Amylase Activity Assay. Amylase activity was estimated as in Savel'ev et al. (2001) and Kanyshkova et al. (2003). The reaction mixture $(15 \mu \mathrm{L})$ containing $30 \mathrm{~m} M$ Tris-HCl (pH 7.5), $2 \mathrm{~m} M$ maltoheptaose (molecular mass $1,153.0 \mathrm{~g} / \mathrm{mol}$ ), and 0.34 to $0.7 \mu M$ IgG or sIgA was incubated for $24 \mathrm{~h}$ at $37^{\circ}$ using the pseudo first-order reaction conditions. Products of hydrolysis were identified by thin-layer chromatography on Kieselgel plates (Merck) using acetic acid-1-butanol- $\mathrm{H}_{2} \mathrm{O}$ (4:12:4). The activities of IgG and sIgA were estimated from the scanning data as a relative percentage of intact maltoheptaose and its hydrolyzed forms. For each Abs preparation, the optimal concentration was found to take all measurements within the linear parts of the time dependencies and Abs concentration. Finally, all relative activities were normalized to $0.47 \mu M \mathrm{IgG}$ and sIgA and $24 \mathrm{~h}$ of the incubation.

Peroxidase Activities Assay. Measurements of the $\operatorname{IgG}$ and $\mathrm{sIgA} \mathrm{H}_{2} \mathrm{O}_{2}$-dependent peroxidase activities were carried using $25 \mathrm{mM}$ potassium-phosphate $(\mathrm{pH}$ 6.8), $10 \mathrm{mM} \mathrm{H} \mathrm{H}_{2} \mathrm{O}_{2}, 0.2 \mathrm{mg} / \mathrm{mL} 3,3^{\prime}$-diaminobenzidine (molecular mass $214.27 \mathrm{~g} / \mathrm{mol}$ ), and $6.6 \mu M$ IgG or sIgA as in Tolmacheva et al. $(2018,2019)$. The reaction mixtures $(0.2 \mathrm{~mL})$ were performed in multiwell plates in the dark at $23^{\circ} \mathrm{C}$ depending on the relative activity of Abs for 0.5 to 20 min. Optical density $\left(\mathrm{A}_{450}\right)$ of the reaction mixtures was determined using a Labsystems Uniskan II plate reader (Labsystems Diagnostics). Reaction mixtures containing no Abs were used as controls. All measurements (initial rates from the reactions) were taken within the time courses' linear regions and Abs concentration curves. Finally, the relative activities were normalized using $k_{\text {cat }}$ values: $k_{\text {cat }}=\mathrm{V}(M / \min ) /$ [Abs], $M$, where $\mathrm{V}=$ reaction rate.

Protease Activity Assay. Azocasein was used as a substrate to analyze the proteolytic activity of $\operatorname{IgG}$ and sIgA as in Coêlho et al. (2016). The reaction mixture $(30 \mu \mathrm{L})$ contained $100 \mathrm{~m} M$ Tris- $\mathrm{HCl}, \mathrm{pH}$ 7.5, $8 \mathrm{~m} M$ $\mathrm{MgCl}_{2}, 4 \mathrm{mM} \mathrm{CaCl}, 5.0 \mathrm{mg} / \mathrm{mL}$ of azocasein, and 1.0 to $3.0 \mu M \mathrm{IgG}$ or sIgA. The mixtures were incubated at $37^{\circ} \mathrm{C}$ for $24 \mathrm{~h}$ and stopped by adding $24 \mu \mathrm{L}$ of $20 \%$ trichloroacetic acid, centrifuged at 13,000 rpm for $1 \mathrm{~min}$ to remove the insoluble precipitate. An equal volume of 1 $M \mathrm{NaOH}$ was added to the supernatant and incubated for $30 \mathrm{~min}$ at room temperature. The mixture was then used for centrifugation at 13,000 rpm for $3 \mathrm{~min}$, and the supernatant was collected. The supernatant's optical density was measured at a wavelength of $436 \mathrm{~nm}$ on a Genesys 10S UV-Vis spectrophotometer (Thermo Fisher Scientific Inc.). The increase in the solution's optical density occurred as a result of the cleavage of the azo dye from casein was estimated. All measurements were performed using linear dependences of reaction rate on the concentration of $\operatorname{IgG}$ and $\operatorname{sIgA}$ and the incubation time corresponding to the conditions of pseudo firstorder reaction. Finally, the relative protease activity was normalized to $\Delta \mathrm{A}_{436} / 24 \mathrm{~h}$.

RNase Activity Assay. Reaction mixtures (0.35 $\mathrm{mL})$ contained $50 \mathrm{~m} M$ HEPES $(\mathrm{pH} 7.5)$ and $50 \mu \mathrm{g} /$ $\mathrm{mL}$ poly $(\mathrm{U})$ or poly $(\mathrm{C})$ as in Krasnorutskii et al. (2008, 2009). The hydrolysis reaction was started by the adding of IgG or sIgA to a final concentration of $2.6 \mu \mathrm{M}$, and the mixtures were incubated during 0 to $50 \mathrm{~min}$ at $30^{\circ} \mathrm{C}$. The rate of these RNA hydrolysis was measured from the change of optical density at $282 \mathrm{~nm}$ for poly(U) (Irie et al., 1984) and at $250 \mathrm{~nm}$ for poly(C) (Fisher et al., 1998) for $30 \mathrm{~min}$, similar to the analysis of canonic RNase activity. Quartz cuvettes $(0.3 \mathrm{~cm})$ and a Genesys 10S UV-Vis spectrophotometer were used. All measurements were performed using linear dependences of reaction rate on the concentration of $\operatorname{IgG}$ and the incubation time corresponding to the conditions of pseudo first-order reaction. Finally, the relative RNase activity was normalized to $\Delta \mathrm{A}$ at 282 or $250 \mathrm{~nm} / 30 \mathrm{~min}$.

Application of Strict Criteria. Using several strict criteria for assigning the enzymatic activities directly to Abs (Paul et al., 1989; Nevinsky and Buneva, 2005), it was earlier shown that all 6 activities indicated above are activities of IgG and sIgA from the milk of healthy women (Buneva et al., 1994, 2003; Savel'ev et al., 2001; Odintsova et al., 2005; Nevinsky, 2010, 2011, 2016, 2017; Kompaneets et al., 2020a,b). To prove that 
all activities belong to the milk IgG and $\operatorname{sg} \mathrm{A}$ used in this work, we prepared mixtures of equal amounts of 7 preparations of $\operatorname{IgG}\left(\operatorname{IgG}_{\text {mix }}\right)$ and $\operatorname{sIg} \mathrm{A}\left(\operatorname{sIg} \mathrm{A}_{\text {mix }}\right)$. Analysis of all 6 activities was performed after SDSPAGE of $\operatorname{IgG}_{\text {mix }}$ and $\operatorname{sig} \mathrm{A}_{\text {mix }}$, according to (Buneva et al., 2003; Kanyshkova et al., 2003; Aulova et al., 2017). After standard SDS-PAGE of the Abs, to restore their activities, SDS was removed by incubation of the gels for $1 \mathrm{~h}$ at $30^{\circ} \mathrm{C}$ with $4 M$ urea and then washed 9 times (10-15 min) with $\mathrm{H}_{2} \mathrm{O}$. Then 2- to 3-mm cross-sections of several parallel gel longitudinal slices were cut up, thoroughly pounded, and incubated with 50 to $100 \mu \mathrm{L}$ of $20 \mathrm{~m} M$ Tris- $\mathrm{HCl}$, pH 7.5, containing $40 \mathrm{~m} M \mathrm{NaCl}$ for 6 to $7 \mathrm{~d}$ at $4^{\circ} \mathrm{C}$ to allow protein refolding and eluting from the gel. The gels were separated from solutions by centrifugation, and extracts obtained were used for assay of 6 enzymatic activities as described above. Parallel control longitudinal gel lanes were subjected to Coomassie R250 staining for detecting the position of intact IgG and sIgA.

Analysis of the Toxic Effect of Abs on Fertilization and Development of Sea Urchin Embryos. Adult sea urchins Strongylocentrotus intermedius were collected from Peter the Great Bay, Sea of Japan. During the development of sea urchins S. intermedius, 26 stages were identified (Buznikov and Podmarev, 1975). All 26 stages of sea urchin development are shown in Supplemental Table S1 (https://doi.org/10.6084/m9 .figshare.14038952). Male and female gametes were received and fertilized; the standard sea urchin sperm cell toxicity test was used according to Buznikov and Podmarev (1975).

The effect of milk IgG and sIgA on fertilized sea urchin eggs (embryotoxicity) was analyzed as described below. Eggs fertilized $(2,500 / \mathrm{mL})$ were washed from sperm with seawater and placed in 1-mL wells of 24well plates, and a maximum volume (up to $100 \mu \mathrm{L}$ ) of tested Abs to the final 1.0 to $3.0 \mu M$ concentration was added. Embryos were incubated at 20 to $21^{\circ} \mathrm{C}$. The developmental stages of the sea urchin (4-8 blastomeres, early blastula, late gastrula, and pluteus; see Supplemental Table S1) were observed using a Motic 101M microscope (Speed Fair Co. Ltd.). At the stage of 2 to 4 blastomeres, 98 to $100 \%$ division was shown, and further to the stage of the middle blastula (hatching) in all experiments, the embryos developed as in the control. This indicates that in the presence of Abs, protein biosynthesis at the early stages of embryogenesis and the embryo's genome function normally. Slight lysis of embryos, in comparison with the control, appeared after the stage of the late gastrula; it is possible that the constant presence of even $2.6 \mu M$ Abs has an unfavorable effect on the process of late embryogenesis.
The effect of milk Abs on sea urchin sperm (sperm toxicity) was analyzed as follows. A suspension of 200 $\mu \mathrm{L}$ of sperm cells (15 million/mL) in seawater was placed into each of the wells of 96 -well plates, and 20 $\mu \mathrm{L}$ of solutions of the tested Abs (experimental and control) were added to their final concentration of 1.0 to $2.6 \mu M$.

It was shown earlier that IgG and IgA from sera of healthy humans do not possess catalytic activities (Nevinsky, and Buneva, 2003, 2005; Nevinsky, 2010, 2011, 2016, 2017). Therefore, we selected 7 preparations of native Abs from sera of healthy humans (4 women and 3 men) without catalytic activities and used their equimolar mixtures for the negative control. In addition, IgG, IgA, and sIgA Abs completely lose their catalytic activities after incubation at $60^{\circ} \mathrm{C}$ for 60 min (Andrievskaya et al., 2000, 2002). Therefore, we incubated $\operatorname{IgG}_{\text {mix }}$ and $\operatorname{sg} \mathrm{A}_{\text {mix }}$ from women's milk using these conditions and tested their 6 catalytic activities. It has been shown that these Abs do not possess any of the 6 catalytic activities. These preparations of IgG and $\operatorname{sIg} \mathrm{A}$ were used as a second negative control. It was shown previously that IgG from the blood of SLE patients possess increased cytotoxicity (Kozyr et al., 1998; Nevinsky and Buneva, 2003) and catalyze the hydrolysis of DNA and RNA (Andrievskaya et al., 2000, 2002), proteins (Bezuglova et al., 2011, 2012), and oligosaccharides (Savel'ev et al., 1999) as well as have redox activity (Tolmacheva et al., 2019). As a positive control, we used an equimolar mixture of $\mathrm{IgG}$ preparations from the blood of 7 SLE (sle- $\operatorname{IgG}_{\text {mix }}$ ) patients, showing high activity in all the above chemical reactions.

The cells were incubated for $30 \mathrm{~min}$ at $4^{\circ} \mathrm{C}$, and then 100,50 , and $25 \mu \mathrm{L}$ of sperm suspension were added to $1 \mathrm{~mL}$ of unfertilized eggs placed in 24-well plates. Thus, each substance was tested at ratios where there are 600,300, and 150 sperm cells per one egg cell. The optimal amount for studying the toxicity of Abs against urchin sperm was 150 sperm cells per 1 egg cell. The number of fertilized eggs when adding untreated with sperm Abs was taken as $100 \%$ of fertilization. Next, we estimated the percent of fertilized eggs, division to 2 and 4 blastomeres, and the further development of early embryos to the blastula stages.

Toxicity of Antibodies Against Tumor Cells. The cytotoxicity of IgG and sIgA against tumor cells was investigated using MCF-7 human breast adenocarcinoma cells as in Zakharova et al. (2016). The MCF-7 cells were cultured in Iscove's modified Dulbecco's medium (IMDM) in the presence of $40 \mu \mathrm{g} / \mathrm{mL}$ gentamicin, $150 \mathrm{mg} / \mathrm{mL}$ streptomycin, $5 \mathrm{mg} / \mathrm{mL}$ fungizone, and $10 \%$ fetal bovine serum in an atmosphere of $5 \% \mathrm{CO}_{2}$ at $37^{\circ} \mathrm{C}$ 
until a monolayer was formed. Then the medium was discarded, washed several times with PBS buffer (150 $\mathrm{m} M \mathrm{NaCl}, 17 \mathrm{~m} M \mathrm{KH}_{2} \mathrm{PO}_{4}$, and $52 \mathrm{mM} \mathrm{Na} 2 \mathrm{HPO}_{4}$ ). Next, $150 \mu \mathrm{L}$ of $0.25 \%$ trypsin-EDTA solution was added to remove cells from the surface of the culture flask. The resulting suspension was incubated for $40 \mathrm{~min}$ at $37^{\circ} \mathrm{C}$. When the cells were completely detached from the surface of the cultured flask, the IMDM medium was added, thoroughly suspended, replaced with a new one, then these cells were plated into a 96 -well plate, $100 \mu \mathrm{L}$ per well, concentration $2 \times 10^{5}$ cells $/ \mathrm{mL}$, and incubated for $24 \mathrm{~h}$. Then, preparations of IgG or sIgA were added at final concentrations of 1.0 to $8.8 \mu M$, and the growth of the cell culture was monitored for $3 \mathrm{~d}$. Cells grown in the presence of human serum albumin, native IgG from healthy humans, as well as milk IgG and sIgA without catalytic activities (see above) at final concentrations of 1 to $6 \mu M$ were used as negative controls. As a positive control, we used sle-IgG $\mathrm{I}_{\text {mix }}$, showing high activity in all the chemical reactions (see above).

Cells grown in the absence of proteins were also used as a control. For each concentration of the component added, the study was conducted in triplicate. The determination of cytotoxicity was carried out according to the method of the standard colorimetric 3-(4,5-dimethylthiazol-2-yl)-2,5-diphenyl-2H-tetrazolium bromide (MTT) test (Mosmann, 1983). The test used is based on the ability of mitochondrial dehydrogenases to convert colorless water-soluble MTT into colored formazan, which crystallizes inside the cell. The enzymes of nonviable cells do not function, so these cells are not stained with MTT. After incubation of the cells with the Abs, $20 \mu \mathrm{L}$ of $1 \mathrm{mg} / \mathrm{mL}$ MTT was added to the plate wells; the cells were incubated for 3 $\mathrm{h}$ at $37^{\circ} \mathrm{C}$. The medium was removed, the formed dark violet crystals of formazan were dissolved in $100 \mu \mathrm{L}$ of isopropanol, and the optical density of the solution was measured on a Uniscan scanner (Thermo Scientific) at 2 wavelengths of 570 and $620 \mathrm{~nm}$. The value characterizing the cytotoxic activity of the Abs preparations was determined from the decrease in living cells.

\section{Statistical Analysis}

The relative activities of $\operatorname{Ig} \mathrm{G}$ and $\operatorname{sIg} \mathrm{A}$ preparations were estimated in the catalysis of different reactions. The results obtained were reported as the mean and the standard deviation of at least 3 independent experiments for each Abs preparation. Shapiro-Wilk's W test criterion was used to analyze the normality of the distribution of different values sets obtained. The relative activities of some $\operatorname{IgG}$ and sIgA sample sets did not correspond to the normal Gaussian distribution. The nonparametric ranking method of Spearman, therefore, was used for the correlation analysis. The possible differences between the sample sets were analyzed using the Mann-Whitney $\mathrm{U}$ test; the sets demonstrating $P<$ 0.05 were considered statistically different.

\section{RESULTS}

\section{Purification and Characterizing of IgG and SIgA}

Electrophoretically homogeneous IgG and $\operatorname{sIgA}$ were separated from proteins of 7 human milk samples according to Kit et al. (1996), Nevinsky et al. (1998), Gorbunov et al. (2000, 2005), and Karataeva et al. (2006a,b) by sequential chromatography first on Protein G-Sepharose (to separate IgG). The fraction eluted under loading on Protein G-Sepharose was applied to Protein A-Sepharose to obtain sIgA. Then both columns were washed using conditions that remove nonspecifically bound proteins. The IgG and sIgA were specifically eluted from the affinity columns with acidic buffer ( $\mathrm{pH}$ 2.6). Then IgG and sIgA fractions were additionally purified using FPLC gel filtration in an acidic buffer $(\mathrm{pH}=2.6)$, destroying immune complexes as in Kit et al. (1996), Nevinsky et al. (1998), Gorbunov et al. (2000, 2005), and Karataeva et al. (2006a,b).

It was previously shown in many articles (for reviews, see Nevinsky, and Buneva, 2003, 2005; Keinan, 2005; Nevinsky, 2010, 2011, 2016, 2017) that Abs obtained using this approach are electrophoretically and immunologically homogeneous and do not contain any admixtures of any canonical enzymes. In addition, it was demonstrated that IgG and sIgA from the milk of healthy women contain subfractions of ABZ that hydrolyze DNA, RNA (Buneva et al., 1994, 2003; Kompaneets et al., 2020a,b), proteins (Odintsova et al., 2005), and oligosaccharides (Savel'ev et al., 2001), and also possess peroxidase activity (Nevinsky, 2010, 2011, 2016, 2017). However, all these enzymatic activities of dairy $\operatorname{IgG}$ and $\operatorname{sg} \mathrm{A}$ were found over a long period of time using such preparations from the milk of different lactating mothers. In this work, for the first time, all of these activities were assessed using both IgG and sIgA preparations from the same milk samples of 7 mothers. Figure 1 shows typical examples of several catalytic activities of IgG and sIgA determination as described above.

To prove that all activities belong to the milk IgG and $\operatorname{sIgA}$, we prepared mixtures of equal amounts of 7 preparations of $\operatorname{IgG}\left(\operatorname{IgG}_{\text {mix }}\right)$ and $\operatorname{sIg} A\left(\operatorname{sg} A_{\text {mix }}\right)$.

It was shown that $\operatorname{IgG}_{\text {mix }}$ and $\mathrm{sIgA}_{\text {mix }}$ were electrophoretically homogeneous (Figure 2a). To exclude possible artifacts due to traces of contaminating enzymes, 
the $\operatorname{IgG} \mathrm{G}_{\text {mix }}$ and $\operatorname{sIg} \mathrm{A}_{\text {mix }}$ were separated by SDS-PAGE, and their enzymatic activities were detected after the extraction of proteins from excised gel slices (Figure 2 ). The detection of all activities in the gel region cor- responding only to $\operatorname{IgG}_{\text {mix }}(150 \mathrm{kDa})$ and $\operatorname{sIg} \mathrm{A}_{\text {mix }}(385$ $\mathrm{kDa}$ ), as well as the absence of any other protein bands and peaks of the activities, provided direct evidence that $\operatorname{sIg} \mathrm{A}_{\text {mix }}$ (Figures $2 \mathrm{~b}$ and $2 \mathrm{c}$ ) and $\operatorname{Ig} \mathrm{G}_{\text {mix }}$ (Figures $2 \mathrm{~d}$ a)

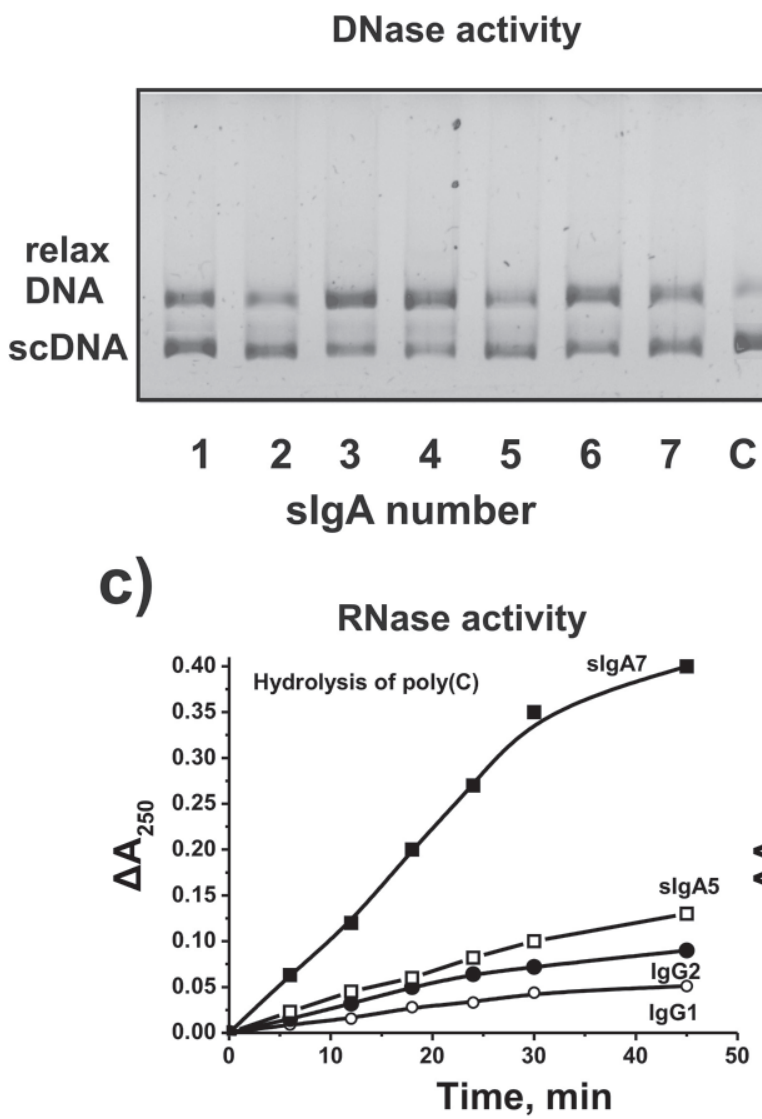

b)

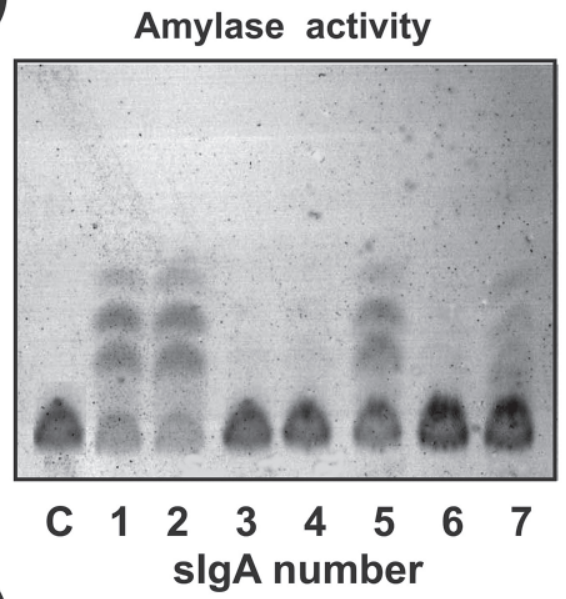

e)

d)
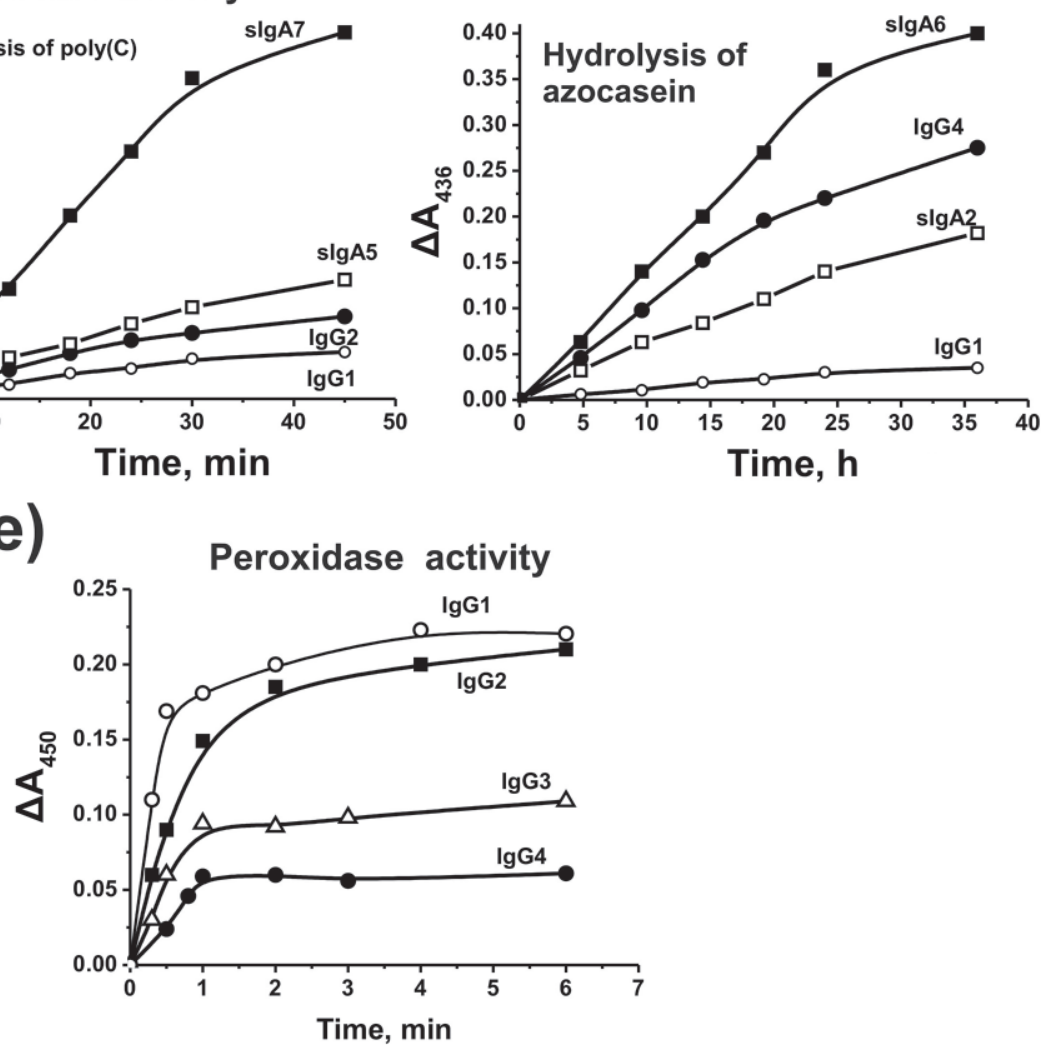

Figure 1. Typical examples of assessing the relative enzymatic activities of $\operatorname{IgG}$ and secretory $\operatorname{IgA}$ (sIgA) in the reaction of hydrolysis of supercoiled (sc) DNA (a), oligosaccharide-maltoheptaose (b), RNA (c), azocasein (d), and oxidation of 3,3'-diaminobenzidine (e). Lane C (panels $\mathrm{a}$ and b) corresponds to the activity in the absence of antibodies. The DNase activity was analyzed by agarose gel electrophoresis (a), amylase activity using thin-layer chromatography (b); RNase [hydrolysis of poly $(\mathrm{C})]$ (c), protease (d), and peroxidase (e) activities by analyzing changes in optical density $(\Delta \mathrm{A}$, absorbance) at different wavelengths $(250,436$, and 450$)$. IgG and sIgA were used in different concentrations (0.26-4.6 $\mu M$; see Materials and Methods). 

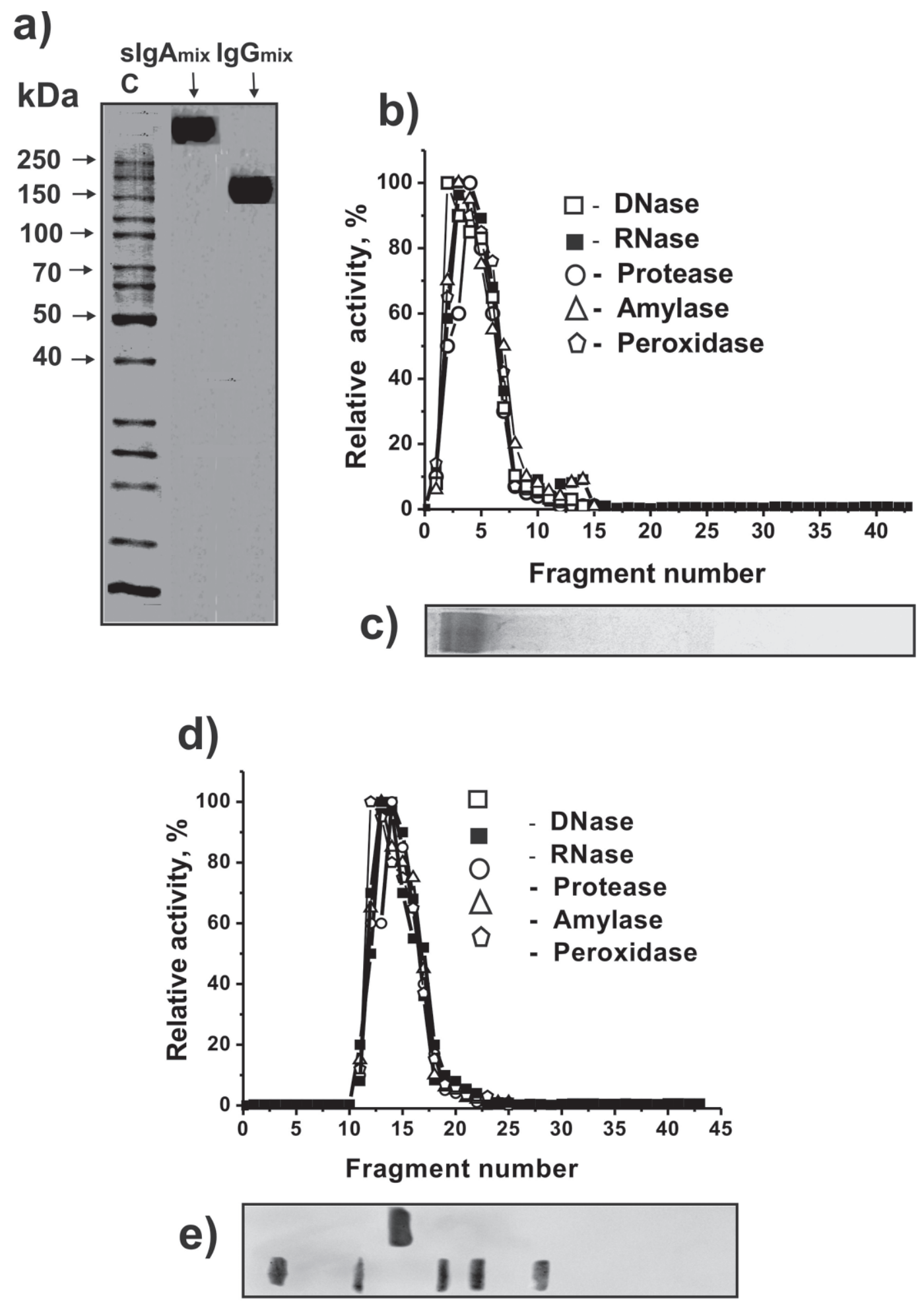

Figure 2. Sodium dodecyl sulfate-PAGE analysis of homogeneity of secretory $\operatorname{IgA}$ mix $\left(\operatorname{sIgA}_{\text {mix }}\right)$ and $\operatorname{IgG} G_{\text {mix }}(11 \mu \mathrm{g})$ from breast milk in a nonreducing 4 to $16 \%$ gradient gel followed by silver staining (a). Lane C indicates the positions of proteins with known molecular mass. Verification of the criterion proving that $\operatorname{sg} A_{\text {mix }}$ and $\operatorname{IgG}_{\text {mix }}$ catalyze several reactions. After SDS-PAGE of $\operatorname{sgA} A_{\text {mix }}$ and $\operatorname{IgG} G_{\text {mix }}$ in $4 \%$ to $16 \%$ gradient gel, the relative activity in catalysis of different reactions were estimated using the extracts of longitudinal slices of the gel 3- to 4-mm fragments in the case of $\operatorname{sIgA}_{\text {mix }}$ (b) and $\operatorname{IgG}_{\text {mix }}$ (d). The maximum values of all activities were taken as $100 \%$. Additional longitudinal control slices of the same gels were treated with Coomassie R250; (c) corresponds to coloring of sIgA, whereas (e) corresponds to painting of IgG and standard protein markers. The error in the relative activity determination ( 2 independent experiments) in each reaction did not exceed 10 to $20 \%$ (b and d). For details, see Materials and Methods. 
Table 1. Relative activities of IgG preparations in the catalysis of 6 different reactions ${ }^{1}$

\begin{tabular}{|c|c|c|c|c|c|c|}
\hline Item & $\begin{array}{c}\text { DNase, } \% \text { of } \\
\text { DNA hydrolysis; } \\
{[\mathrm{IgG}]=0.26 \mu M}\end{array}$ & $\begin{array}{c}\text { Amylase, } \\
\% \text { of hydrolysis; } \\
{[\operatorname{IgG}]=0.47 \mu M}\end{array}$ & $\begin{array}{l}\text { Peroxidase; } \\
k_{\text {cat }}, \min ^{-1}\end{array}$ & $\begin{array}{c}\text { Protease } \\
\text { activity, } \Delta \mathrm{A}_{436} \\
{[\mathrm{IgG}]=2.7 \mu M}\end{array}$ & \multicolumn{2}{|c|}{ RNase; $[\operatorname{IgG}]=2.6 \mu M$} \\
\hline $\begin{array}{l}\text { Activity number } \\
\text { IgG number }\end{array}$ & 1 & 2 & 3 & 4 & 5 & 6 \\
\hline $\mathrm{IgG1}$ & $16.0 \pm 1.4$ & $5.5 \pm 0.5$ & $76 \pm 6.0$ & $0.03 \pm 0.002$ & $0.044 \pm 0.003$ & $0.03 \pm 0.002$ \\
\hline $\operatorname{IgG} 2$ & $33.4 \pm 2.4$ & $6.7 \pm 0.6$ & $84 \pm 7.0$ & $0.2 \pm 0.02$ & $0.072 \pm 0.006$ & $0.026 \pm 0.002$ \\
\hline IgG3 & $20.0 \pm 1.7$ & $10.5 \pm 0.9$ & $100 \pm 8.0$ & $0.034 \pm 0.003$ & $0.066 \pm 0.005$ & $0.034 \pm 0.003$ \\
\hline IgG6 & $5.0 \pm 0.5$ & $3.9 \pm 0.4$ & $38 \pm 4.0$ & $0.04 \pm 0.003$ & $0.05 \pm 0.003$ & $0.034 \pm 0.002$ \\
\hline IgG7 & $37.6 \pm 3.4$ & $8.8 \pm 0.9$ & $128 \pm 11.0$ & $0.14 \pm 0.01$ & $0.07 \pm 0.006$ & $0.028 \pm 0.002$ \\
\hline Average value & $24.6 \pm 13.2$ & $7.7 \pm 2.6$ & $100 \pm 42$ & $0.12 \pm 0.08$ & $0.06 \pm 0.01$ & $0.03 \pm 0.004$ \\
\hline
\end{tabular}

${ }^{1}$ For each value, a mean of 3 measurements is given. $k_{\text {cat }}=\mathrm{V}(M / \min ) /[\mathrm{Abs}], M$, where $\mathrm{V}=$ reaction rate. $\Delta \mathrm{A}_{436}, \Delta \mathrm{A}_{250}$, and $\Delta \mathrm{A}_{282}$ correspond to the changes in the absorption of reaction mixtures at wavelengths 436,250 , and $282 \mathrm{~nm}$, respectively.

${ }^{2}$ Correlation coefficient $(\mathrm{r})$ : between values corresponding to different activities: $1-2(0.69) ; 1-3(0.86) ; 1-4(0.88) ; 1-5(0.69) ; 1-6(-0.04) ; 2-3$ (0.86); 2-4 (0.42); 2-5 (0.29); 2-6 (0.44); 3-4 (0.65); 3-5 (0.38); 3-6 (0.41); 4-5 (0.62); 4-6 (0.0005); 5-6 (-0.34).

and 2e) are not contaminated with canonical DNases, RNases, proteases, amylases, and peroxidases.

\section{Catalytic Activities of IgG and SIgA}

In addition, it was interesting whether auto-Abs possess cytotoxicity and, if they do, whether their toxicity is associated with any of the enzymatic activities of the ABZ included in their composition. Table 1 shows data on the relative activities of IgG Abs in the catalysis of 6 reactions. It can be seen that each $\operatorname{IgG}$ preparation is characterized by a specific ratio of relative activity in the hydrolysis of DNA, RNA $[\operatorname{poly}(\mathrm{C})$ and poly(U)], protein, oligosaccharide, and peroxidase oxidation of the substrate.
Interestingly, the DNase activity of $\operatorname{IgG}$ preparations correlates well with all activities (correlation coefficient, $\mathrm{r}=0.68$ to 0.88 ) except for the hydrolysis of $\operatorname{poly}(\mathrm{U})$ $(\mathrm{r}=-0.04)$. The $\mathrm{r}$ of amylase activity with 4 other activities are positive and vary from 0.29 [hydrolysis of poly $(\mathrm{U})$ ] to 0.86 (peroxidase activity; Table 1 ). The peroxidase activity of $\operatorname{IgG}$ also positively correlates with all other activities ( $\mathrm{r}=0.38$ to 0.86 ). A good positive correlation of the protease activity of IgG with the other 5 activities ( $r=0.42$ to 0.88 ) was revealed; a very weak correlation only with the hydrolysis of poly(U) (0.0005) was observed. Interestingly, the activity of IgG in the hydrolysis of poly $(\mathrm{C})$ is characterized by positive correlations with 5 other activities $(\mathrm{r}=0.29$ to 0.69$)$ except the hydrolysis of poly $(\mathrm{U})$; in this case, a negative

Table 2. Relative activities of secretory $\operatorname{IgA}(\operatorname{sgA})$ preparations in the catalysis of 6 different reactions ${ }^{1}$

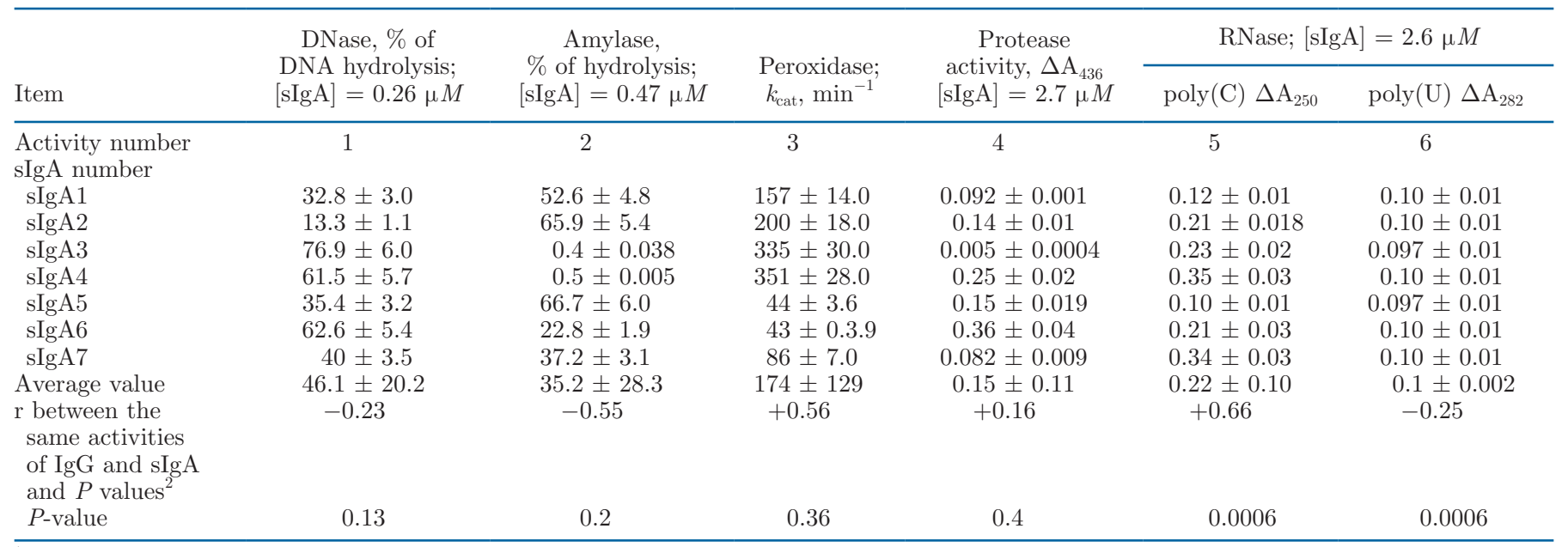

${ }^{1}$ For each value, a mean of 3 measurements is given. $k_{\text {cat }}=\mathrm{V}(M /$ min $) /[\mathrm{Abs}], M$, where $\mathrm{V}=$ reaction rate. $\Delta \mathrm{A}_{436}, \Delta \mathrm{A}_{250}$, and $\Delta \mathrm{A}_{282}$ correspond to the changes in the absorption of reaction mixtures at wavelengths 436,250 , and $282 \mathrm{~nm}$, respectively.

${ }^{2}$ Correlation coefficient $(\mathrm{r})$ : between values corresponding to different activities: $1-2(-0.92) ; 1-3(0.41) ; 1-4(0.13) ; 1-5(0.35) ; 1-6(-0.32) ; 2-3$ $(-0.63) ; 2-4(-0.12) ; 2-5(-0.63) ; 2-6(0.04) ; 3-4(-0.29) ; 3-5(0.46) ; 3-6(-0.08) ; 4-5(0.08) ; 4-6(0.44) ; 5-6(0.39)$. 
correlation was observed $(\mathrm{r}=-0.34)$. Overall, 5 of 6 enzymatic activities of IgG correlate relatively well and positively, except for the hydrolysis of poly(U). In the case of hydrolysis of poly(U), there is a negative correlation with the activities of $\operatorname{IgG}$ in the hydrolysis of DNA $(-0.04)$, poly $(\mathrm{C})(-0.34)$, and a very low positive correlation with protease activity (0.0005; Table 1$)$.

Table 2 shows the data on the relative activity of sIgA Abs in the catalysis of 6 reactions. Whereas the DNase activity of IgG correlates well and positively with their amylase activity (Table 1), a strong negative correlation $(\mathrm{r}=-0.92)$ is observed in the case of these 2 activities of sIgA Abs (Table 2). In addition, the positive correlations of DNA-hydrolyzing activity of IgG with their other activities (0.67 to 0.88) are much higher than those for the sIgA preparations (0.13 to 0.41). Interestingly, the negative correlation between the activity in the hydrolysis of DNA and poly(U) for $\operatorname{sIgA}(\mathrm{r}=-0.32)$ is significantly higher than that for $\operatorname{IgG}(-0.04)$. Whereas the amylase activity of IgG correlates well and only positively with their other activities (0.29 to 0.86; Table 1$)$, in the case of sIgA, mainly negative correlations are observed $(-0.12$ to -0.92$)$, except very low positive $(\mathrm{r}=0.04)$ with the hydrolysis of poly(U) (Table 2). The relative peroxidase activity positively correlates with 5 other IgG activities ( 0.38 to 0.86 ; Table 1). At the same time, 2 positive correlations of sIgA peroxidase activity with their activity in the hydrolysis of DNA (0.41) and poly (C) (0.46) are relatively low, whereas other $\mathrm{r}$ values are negative $(-0.08,-0.29$, and -0.63 ; Table 2). Protease activity of IgG correlates well and positively with 4 other activities (0.42 to 0.88) except the splitting of poly(U) (0.0005; Table 1$)$. Relatively small positive correlations of the protease activity of $\operatorname{sIg} \mathrm{A}$ were found with their activity in the hydrolysis of poly(C) (0.08), DNA (0.13), and poly(U) $(0.44)$, whereas other $\mathrm{r}$ values of protease activity were negative: amylase activity $(-0.12)$, peroxidase activity $(-0.29$; Table 2$)$. The correlation of the hydrolysis of poly $(\mathrm{C})$ by $\operatorname{sig} \mathrm{A}$ Abs was positive with the splitting of DNA (0.35), poly(U) (0.39), proteins (0.08), and peroxidase activity $(0.46)$, but was negative with amylase activity $(-0.63$; Table 1$)$.

Thus, in the case of IgG of 15 estimated $\mathrm{r}$ values, only 2 were negative, whereas sIgA demonstrated 7 negative $\mathrm{r}$ values (Tables 1 and 2). Such difference in the 6 catalytic activities of IgG and sIgA from the milk of the same 7 women may be related to the various origin of these auto-Abs and corresponding to the subfractions of ABZ.

As was mentioned above, $\operatorname{IgA}$ are produced by Blymphocytes in the mother's Peyer's patch lymphoid cells, and then they migrate to mucosal sites generating local sIgA. The IgG in milk may be partially produced locally by the mammary gland-specific cells and can partially be transferred from the blood circulation system (Mestecky et al., 1986).

It was shown previously that relative average activities of milk sIgA are usually higher than those of IgG (Nevinsky and Buneva, 2005; Nevinsky, 2010). From Tables 1 and 2, it follows that sIgA possess higher activity than IgG (-fold): 1.9 (DNase), 4.6 (amylase), 1.7 (peroxidase), 1.3 (protease), 3.7 (hydrolysis of poly $(\mathrm{C})$ ), and 3.3 [hydrolysis of poly(U)], 1.7 (peroxidase). However, only in the case of the hydrolysis of poly $(\mathrm{C})$ and poly(U) by milk IgG and sIgA, $P<0.05$ (0.0006), and in the case of other enzymatic activities, $P$-values are greater than 0.05 (Table 2).

In addition, the relative content of $\operatorname{sIgA}(\sim 385 \mathrm{kDa})$ in human milk in different periods of lactation (up to $1 \mathrm{mo} ; 1-2 \mathrm{mg} / \mathrm{mL}$ or $2.6-5.2 \mu M$ ) is about $\sim 18$ to 20 times higher than IgG (Jensen et al., 1995; Rechtman et al., 2002). It was interesting to reveal whether Abs from human milk can exhibit any cytotoxic properties and, if they exist, how they can be related to the catalytic activities of the ABZ entering their composition.

Toxicity of IgG and SIgA Toward Urchin Eggs and Sperm. One of the well-known methods for assessing the toxicity of various compounds is to analyze their effect on the ability of male sea urchin sperm to fertilize female eggs (sperm toxicity) as well as the effect of compounds on the development of fertilized sea urchin egg embryotoxicity (Buznikov and Podmarev, 1975). During the development of sea urchins $S$. intermedius, 26 stages were identified. All 26 stages of sea urchin development are shown in Supplemental Table S1 (https: //doi.org/10.6084/m9.figshare.14038952), and some of them in Figure 3 (Buznikov and Podmarev, 1975).

First, an analysis of the embryotoxicity of $\operatorname{IgG}$ and sIgA from human milk was performed. Milk $\operatorname{IgG}, \operatorname{sig} A$, or sle-IgG $G_{\text {mix }}$ were added to fertilized sperm eggs at a final concentration of 1.0 to $2.6 \mu M$. The developmental stages of the sea urchin (4-8 blastomeres, early blastula, late gastrula, and pluteus; Figure 3) were observed. At the stage of 2 to 4 blastomeres, $98 \%$ to $100 \%$ division of eggs was shown, and further to the stage of the middle blastula (hatching), in all experiments, the embryos developed as in the control. This indicates that in the presence of $\operatorname{IgG}$ and $\operatorname{sg} A$ or sle-IgG $\mathrm{Imix}_{\text {mix }}$, biosynthesis of protein at the early stages of embryogenesis and the embryo genome functions normally.

Second, an analysis of the sperm toxicity of $\operatorname{IgG}$ and sIgA from mother's milk was performed. The sperm preparations of sea urchins were preincubated with IgG and $\operatorname{sg} \mathrm{A}$ Abs or sle- $\operatorname{IgG}_{\text {mix }}$ at different concentrations $(1.0-2.6 \mu M)$, and then they were added to the egg suspensions. We estimated the percent of fertilized eggs, division to 2 and 4 blastomeres, and the further devel- 
opment of early embryos to the blastula stage. Figure 4a demonstrates the dependences of the number of unfertilized eggs on the concentration of IgG added to sperm before its addition to native eggs. The toxicity of IgG Abs can be seen in relation to urchin sperm growth with an increase in Abs concentration. However, each IgG preparation exhibits its own level of toxicity. The $\operatorname{IgG}$ from the blood of healthy donors without catalytic activities (c-IgG) and $\operatorname{IgG}$ and $\operatorname{sIg} A$ Abs from human milk subjected to inactivation according to Andrievskaya et al. (2000, 2002) without catalytic activity were used as negative controls. Treatment of sperm with these control Abs did not lead to a decrease in the percent of fertilized eggs (Figures 4a and 4b). However, a mixture of 7 IgG Abs with high catalytic activities from the blood of SLE patients ( $\operatorname{sle}-\operatorname{IgG}_{\text {mix }}$ ) very strongly suppressed the fertilization of eggs (Figure 4a).

Depending on IgG preparation at a concentration of $2.6 \mu M$ (taking into account the lack of effect on sperm of control antibody samples), the number of unfertilized eggs varied from 20 to $80 \%$ (average value $=42.1$ $\pm 22.7 \%$; Table 3 ).

The sIgA preparations exhibited higher cytotoxicity toward urchin sperm compared with IgG samples (Figure $1 \mathrm{~b}$ ). Various sIgA preparations at a concentration of $2.6 \mu M$ showed suppression of the ability of sperm to fertilize eggs from 44.6 to $89.2 \%$ (average value $=62.1$ \pm 18.0 ). Thus, the average cytotoxicity of $\operatorname{sig} A$ was 1.6-fold higher than IgG Abs. However, the $\mathrm{r}$ between the relative toxicity of $\operatorname{IgG}$ and $\operatorname{sIgA}$ is relatively high, $0.82 ; P=0.12$ (Table 3 ).

Cytotoxicity of Milk Antibodies Against Breast Adenocarcinoma MCF-7 Cancer Cells. As mentioned above, DNase ABZ of patients with SLE, lymphoproliferative diseases (Kozyr et al., 1998), and multiple sclerosis (Nevinsky and Buneva, 2003), and Bence Jones proteins of myeloma patients (Sinohara and Matsuura, 2000) are cytotoxic, penetrate into cell

\section{A Sea urchin development}
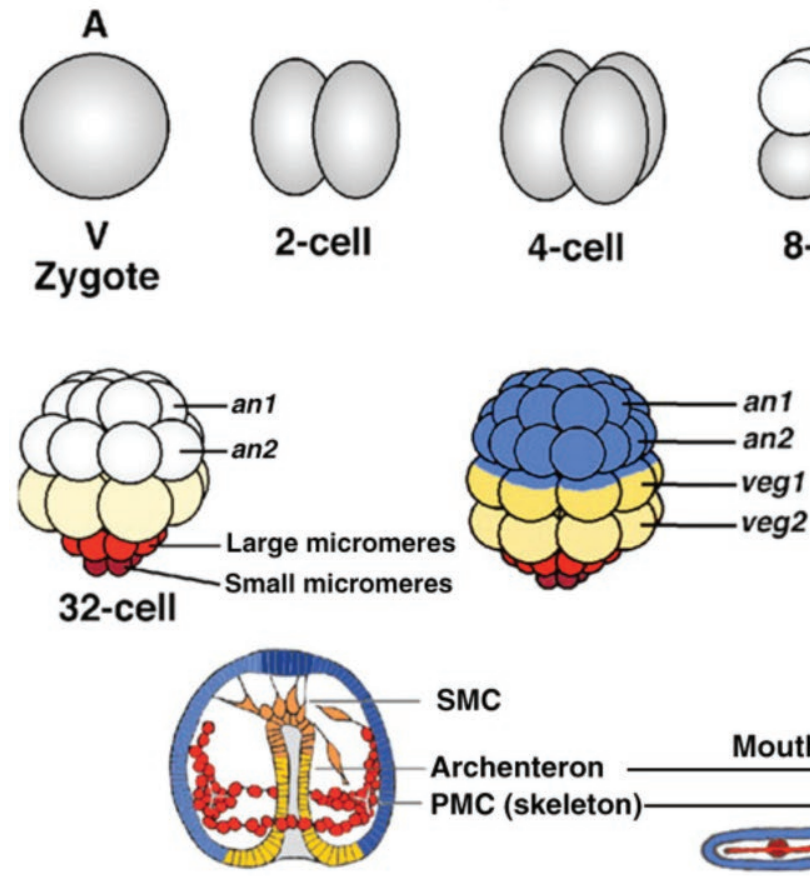

Late gastrula

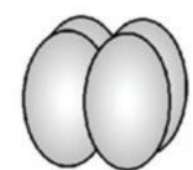

4-cell
SMC

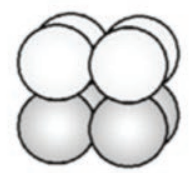

8-cell

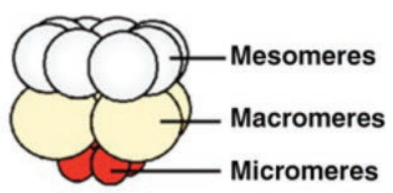

16-cell

Micromeres

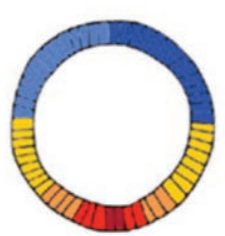

Hatched blastula

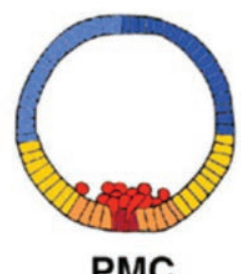

ingression

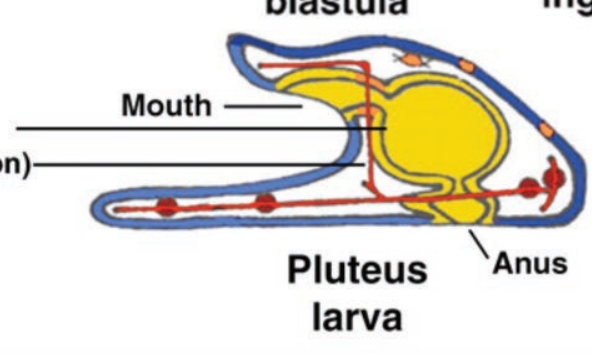

\section{Color key Ectoderm $\quad$ Skeletogenic mesoderm \\ Endoderm Non-skeletogenic mesoderm}

Figure 3. Several of the 26 stages of sea urchin development (Buznikov and Podmarev, 1975). an1 and an2 = 2 layers of embryonic (white, 32 cells) and mature forms of ectoderm (blue color); veg1 and veg2 = 2 layers of endoderm mature forms. $\mathrm{A}=$ animal pole; $\mathrm{V}=$ vegetal pole; $\mathrm{PMC}$ and SMC $=$ primary and secondary mesenchyme cells. 
a)

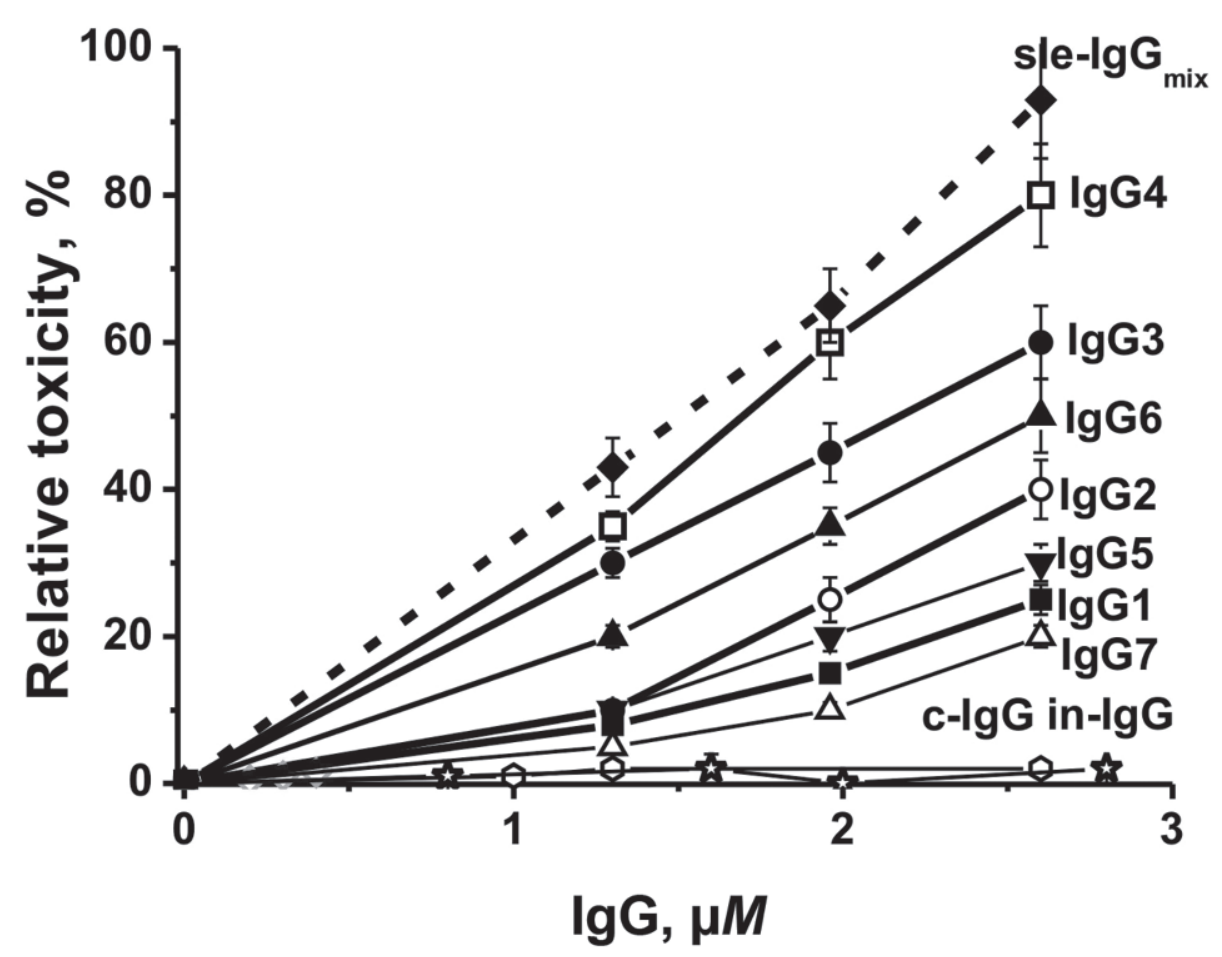

b)

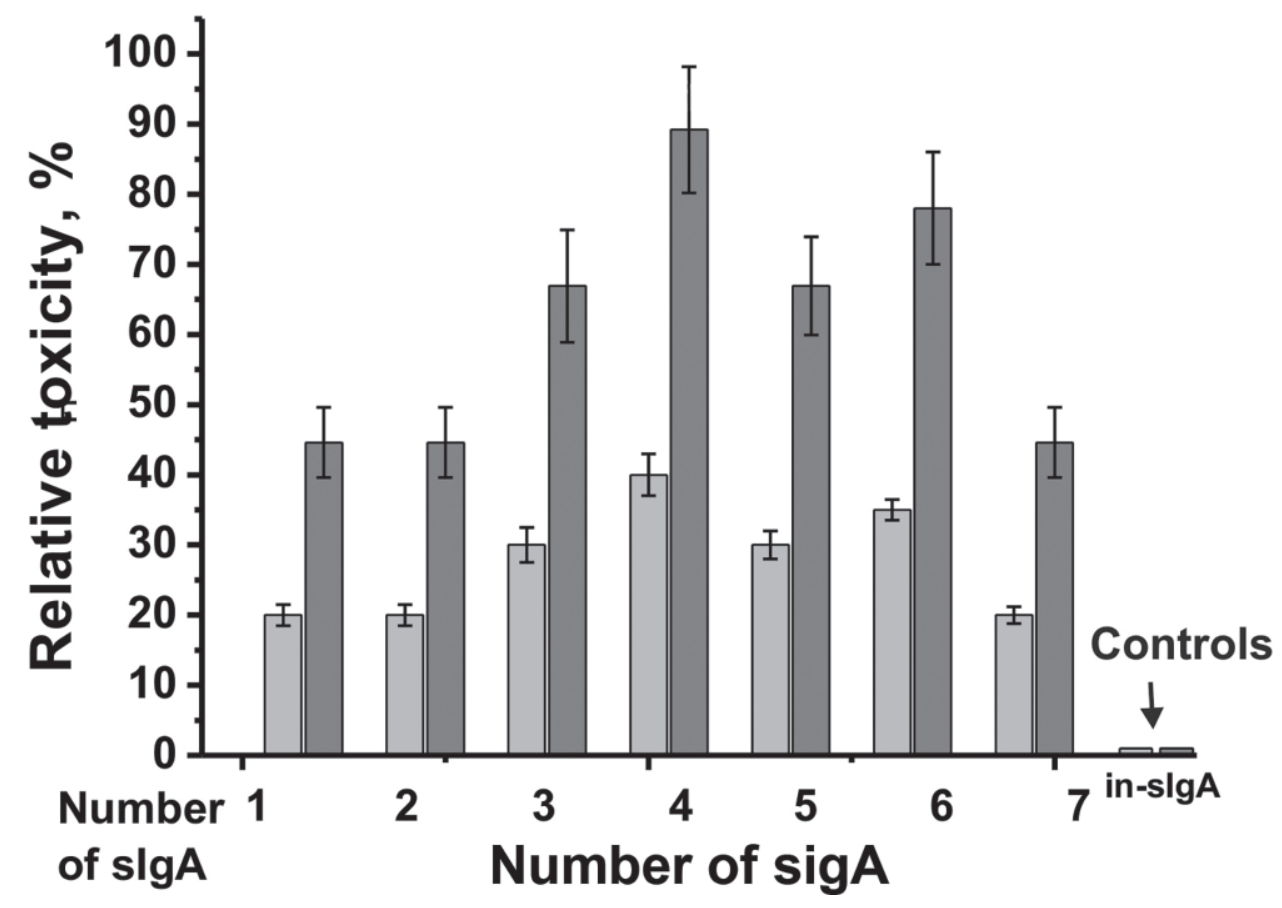

Figure 4. Dependence of the percentage of fertilized eggs after their incubation with sea urchin sperm pretreated with IgG antibodies at different concentrations (a). Percentage of unfertilized eggs after their incubation with sperm pretreated with 1.0 (gray columns) and $2.6 \mu M$ (black columns) of secretory IgA (sIgA) antibodies (b). The IgG from the blood of healthy donors without catalytic activity (c-IgG), and antibodies from human milk subjected to inactivation (in- $\operatorname{IgG}$ and in-sIgA without catalytic activity) were used as negative controls, and sle-IgG $\mathrm{G}_{\text {mix }}$ as positive controls. The error of the values determination varied from 6 to $10 \%$. 
Table 3. The relative toxicity of $\operatorname{IgG}$ and secretory $\operatorname{IgA}(\mathrm{sIgA})$ from the milk of healthy women in relation to the ability of sea urchin sperm treated with these antibodies to fertilize eggs of female sea urchins ${ }^{1}$

\begin{tabular}{|c|c|c|c|c|}
\hline \multirow[b]{2}{*}{ IgG number } & \multirow{2}{*}{$\begin{array}{c}\text { Unfertilized eggs, } \% \\
{[\operatorname{IgG}]=2.6 \mu M^{2}}\end{array}$} & \multirow[b]{2}{*}{ sIgA number } & \multicolumn{2}{|c|}{ Unfertilized eggs, \% } \\
\hline & & & {$[\mathrm{sIgA}]=1.0 \mu M$} & {$[\mathrm{sIg} \mathrm{A}]=2.6 \mu M^{2}$} \\
\hline IgG2 & $40.0 \pm 4.0$ & sIgA2 & $20.0 \pm 1.5$ & $44.6 \pm 5.0$ \\
\hline IgG3 & $60.0 \pm 5.0$ & sIgA3 & $30.0 \pm 2.7$ & $66.9 \pm 8.0$ \\
\hline IgG4 & $80.0 \pm 7.0$ & sIgA4 & $40.0 \pm 5.0$ & $89.2 \pm 9.0$ \\
\hline IgG5 & $30.0 \pm 2.5$ & sIgA5 & $30.0 \pm 3.0$ & $66.9 \pm 7.0$ \\
\hline Average value & $43.6 \pm 21.4$ & Average & $26.4 \pm 7.5$ & $62.1 \pm 18.0$ \\
\hline
\end{tabular}

${ }^{1}$ For each value, a mean of 3 measurements is given.

${ }^{2}$ Correlation coefficient $(\mathrm{r})$ : between $\operatorname{IgG}$ and $\operatorname{sIgA}$ at $2.6 \mu M, \mathrm{r}=0.82 ; P=0.12$.

nuclei, hydrolyze chromatin DNA, and induce apoptosis of cancer cells. It was interesting to see whether the Abs of the milk of healthy women have cytotoxicity toward MCF-7 breast cancer cells.

First, we evaluated the suppression of the growth of cancer cells after adding $\operatorname{IgG}$ at a concentration from 1.0 to $8.8 \mu M$ (Figure 5a). Figure 5b demonstrates the relative decrease in the number of living cancer cells after their incubation with $\operatorname{sIgA}$ at 2 concentrations: 1.0 and $2.6 \mu M$. Treatment of sperm with control BSA, IgG from the blood of healthy (c-IgG), IgG, and $\operatorname{sIg} A$ subjected to inactivation (in-IgG and in-sIgA) without catalytic activities did not have an effect on the relative number of living cancer cells (Figures $5 \mathrm{a}$ and $5 \mathrm{~b}$ ). However, a mixture of IgG (sle- $\operatorname{IgG}_{\text {mix }}$; positive control) with high catalytic activities from the blood of SLE patients very strongly suppressed cancer cell growth (Figure 5a). This is consistent with the literature data that auto-Abs with catalytic activities from the serum of SLE patients usually have the highest activity in suppressing the growth of cancer cells (Kozyr et al., 1998; Nevinsky and Buneva, 2003).

Interestingly, the average value of the decrease in living cells after their incubation with $\operatorname{IgG}(2.6 \mu M)$ was $11.1 \pm 5.1 \%$. The sIgA showed higher levels of cytotoxicity toward cancer cells (Figure 5b), and the average decrease in living cells at their $2.6 \mu M$ concentration was approximately 2.2 -fold higher than in the case of $\operatorname{IgG}(24.1 \pm 11.0 \%$; Table 4$)$. The $\mathrm{r}$ between the relative toxicity of IgG and $\operatorname{sg} \mathrm{A}$ at $2.6 \mu M$ is relatively high, $0.84 ; P=0.02$.

Correlation of Antibody Toxicity with Their Enzymatic Activities. It was interesting to analyze whether the toxicity of the Abs toward sea urchin sperm and MCF-7 tumor cells is related to their catalytic activities. Taking this into account, we analyzed the correlation of the toxicity of IgG and sIgA Abs (Tables
3 and 4) with the relative level of their 6 enzymatic activities using the data for IgG (Table 1) and $\operatorname{sIgA}$ (Table 2).

Since ABZ with DNase activity are cytotoxic (Kozyr et al., 1998; Sinohara and Matsuura, 2000; Nevinsky and Buneva, 2003), it could be expected that the overall toxicity of IgG and sIgA against sperm and MCF-7 cancer cells would correlate with their DNase activity. However, relatively high $\mathrm{r}$ of DNase activity with toxicity toward to sperm (0.71) and cancer cells (0.39) was observed only for sIgA Abs (Table 5). For IgG Abs, the $\mathrm{r}$ values were significantly lower $(0.19$ and 0.1 , respectively).

The maximum positive correlation was observed between the toxicity of $\operatorname{sIg} \mathrm{A}$ Abs in relation to cancer cells and their peroxidase $(\mathrm{r}=0.78)$ and amylase $(\mathrm{r}=$ $0.63)$ activities as well as DNase activity in the case of their toxicity toward urchin sperm $(\mathrm{r}=0.61)$. Interestingly, the proteolytic activity of IgG (0.59) and $\operatorname{sIgA}$ (0.64) correlates well with their sperm toxicity (Table $5)$. At the same time, very weak positive correlations of the protease activity of IgG (0.040) and $\operatorname{sg} A(0.22)$ Abs with their effect on the growth of cancer cells were found (Table 5). A somewhat unexpectedly high level of correlation (0.85) was found for the peroxidase activity of sIgA with their suppressing of the growth of cancer cells. High positive levels of correlation were found for $\operatorname{IgG}$ Abs in the hydrolysis poly(U) with sperm toxicity (0.77) and suppression of cancer cell growth (0.58). A relatively high $\mathrm{r}(0.5)$ between the activity of Abs in the hydrolysis of poly $(\mathrm{C})$ was found only for $\operatorname{sgA}$ in the suppression of the growth of cancer cells. Some $\mathrm{r}$ were negative. For example, particularly high negative $r$ have been found between amylase activity of sIgA and their ability to inhibit the ability of sperm to fertilize eggs $(-0.66)$ and to suppress the growth of cancer cells $(-0.62)$. 


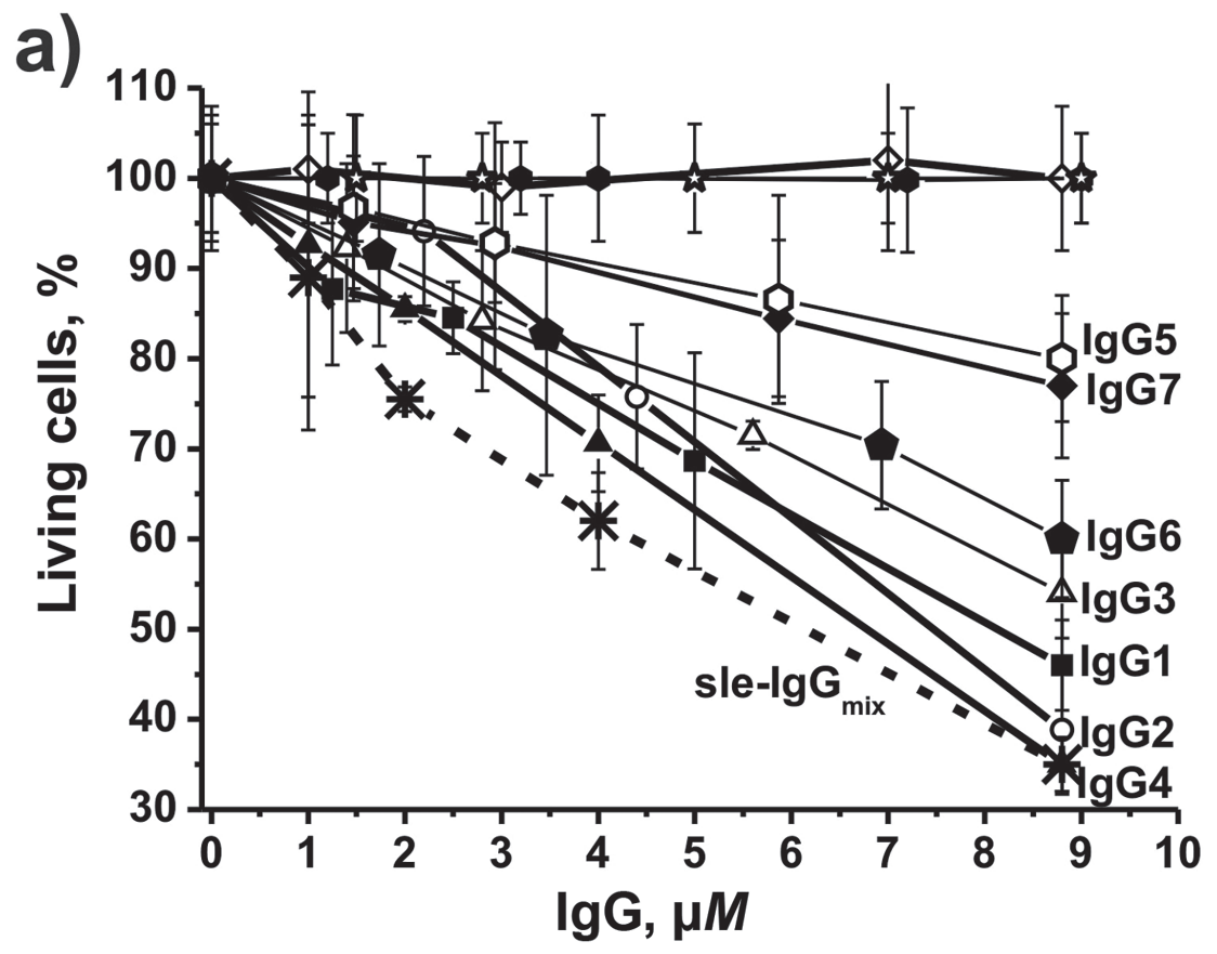

b)

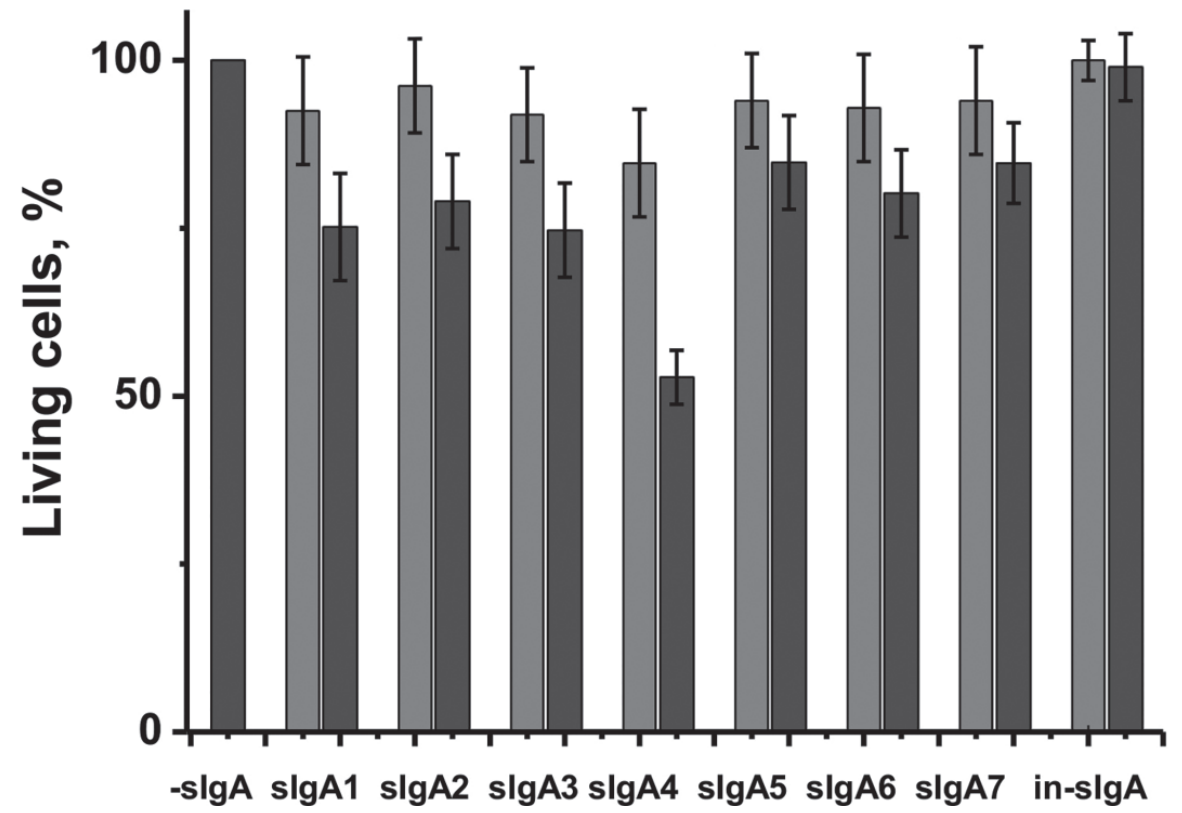

Figure 5. Dependence of the percentage of tumor living MCF-7 cells after their incubation with IgG antibodies at different concentrations (a). Percentage of tumor living MCF-7 cells after their incubation with secretory IgA (sIgA) at 1.0 (gray columns) and $2.6 \mu M$ (black columns) of sIgA antibodies (b). BSA, IgG from the blood of healthy donors without catalytic activity (c-IgG), and antibodies from human milk subjected to inactivation (in-IgG and in-sIgA without catalytic activity) were used as negative, and sle-IgG $\mathrm{m}_{\text {mix }}$ as positive controls. The error of the values determination varied from 6 to $10 \%$. 
Table 4. The relative toxicity of IgG and secretory IgA (sIgA; percent of cell growth inhibition) from the milk of healthy women toward human breast cancer MCF-7 cells ${ }^{1}$

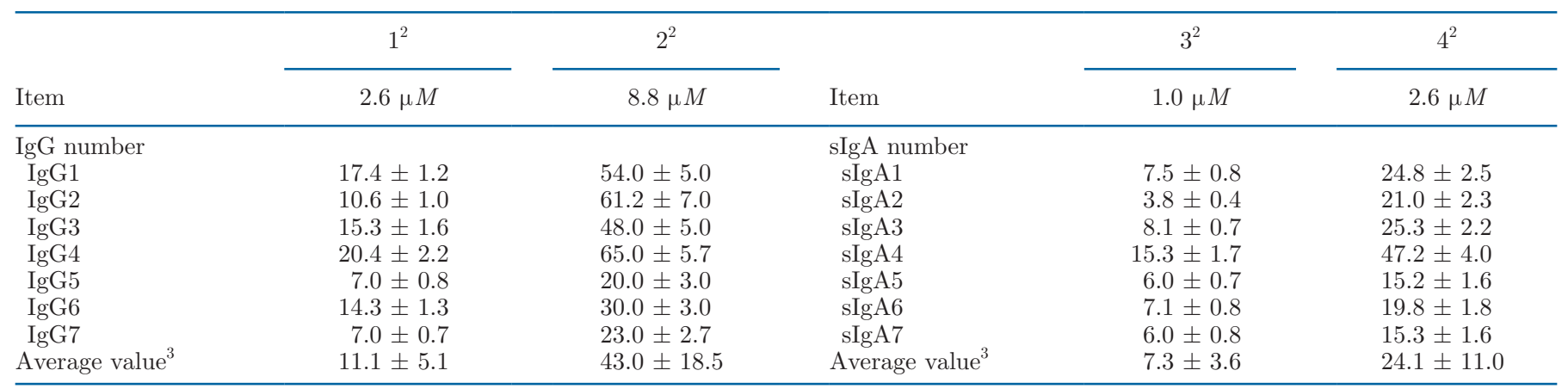

${ }^{1}$ The data on the toxicity of $\operatorname{IgG}$ and $\operatorname{sgA}$ after treatment of sperm at different concentration of antibodies.

${ }^{2}$ Number of parameter.

${ }^{3}$ Difference between 1 and $4=2.2$ fold $(11.1 \pm 5.1 \%$ for $2.6 \mu M \operatorname{IgG}$ vs. $24.1 \pm 11.0 \%$ for $2.6 \mu M \operatorname{sIgA})$. Correlation coefficient (r) and $P$-value: between relative toxicity of IgG and sIgA at $2.6 \mu M(1$ and 4$) ; \mathrm{r}=0.84 ; P=0.02$.

\section{DISCUSSION}

As noted above, among healthy people, only the blood and milk of healthy women contain ABZ that hydrolyze various antigens (see above). The cytotoxicity of IgG Abs from the serum of AID patients against cancer cells was shown earlier (Kozyr et al., 1998; Sinohara and Matsuura, 2000; Nevinsky and Buneva, 2003). However, it was not clear whether ABZ with DNase and other activities from the milk of healthy women have any toxicity. In this work, for the first time, the analysis of the toxicity of IgG and sIgA Abs from human milk was carried out using tests of embryotoxicity and sperm toxicity. It was shown that IgG and sIgA practically do not affect the development of fertilized eggs of the sea urchin, biosynthesis of protein at the early stages of urchin embryogenesis. At the same time, IgG and $\operatorname{sg} A$ were found to be toxic to sea urchin sperm.
After the sperm preincubation with Abs (taking into account the lack of influence on sperm toxicity of control Abs without catalytic activities) at the same concentration $(2.6 \mu M)$ and their addition to eggs, the number of unfertilized eggs in the case of $\operatorname{sIgA}$ was 1.6-fold higher than that for IgG (Table 3). One of the possible reasons for this difference could be that all 6 catalytic activities of sIgA were 1.3 to 4.6 (average value $=2.6 \pm 1.3$ ) times higher than that for IgG Abs. In addition, the relative content of sIgA in human milk in different periods of lactation (up to $1 \mathrm{mo} ; 1-2 \mathrm{mg}$ / $\mathrm{mL}$ or $2.6-5.2 \mu M$ ) is about 18 to 20 times higher than IgG (Hanson et al., 1979, 1994). Taking this into account, it is obvious that the total cytotoxic effect of sIgA of breast milk may be remarkably greater than IgG Abs. At the same time, the maximum cytotoxicity toward cancer cells was found earlier for IgG Abs from the blood of SLE patients (Kozyr et al., 1998; Nevinsky

Table 5. Correlation coefficients of the IgG and secretory $\operatorname{IgA}(\operatorname{sg} A)$ toxicity against sea urchin sperm and breast tumor MCF-7 cells with relative 6 different enzymatic activities of the antibodies ${ }^{1}$

\begin{tabular}{|c|c|c|c|c|c|}
\hline \multirow[b]{2}{*}{ Item } & \multirow[b]{2}{*}{ Amylase } & \multirow[b]{2}{*}{ Peroxidase } & \multirow[b]{2}{*}{ Protease } & \multicolumn{2}{|c|}{ RNase } \\
\hline & & & & $\operatorname{Poly}(\mathrm{C})$ & $\operatorname{Poly}(\mathrm{U})$ \\
\hline \multicolumn{6}{|l|}{ DNase } \\
\hline $\begin{array}{l}\text { IgG antibodies } \\
\quad+0.19 \\
\text { sIgA antibodies }\end{array}$ & +0.49 & +0.38 & +0.59 & +0.15 & +0.77 \\
\hline+0.71 & -0.66 & +0.3 & +0.64 & +0.26 & -0.10 \\
\hline $\begin{array}{l}\text { Tumor cells } \\
\text { IgG antibodies }\end{array}$ & & & & & \\
\hline $\begin{array}{l}+0.1 \\
\text { sIgA antibodies }\end{array}$ & +0.2 & +0.16 & +0.04 & -0.24 & +0.58 \\
\hline+0.39 & -0.62 & +0.85 & +0.22 & +0.5 & +0.24 \\
\hline
\end{tabular}

${ }^{1}$ The data for calculating the correlation coefficients are taken from Tables 1 and 2 (relative enzymatic activities) and Tables 3 and 4 (relative antibody toxicity). 
and Buneva, 2003). These auto-Abs (sle- $\operatorname{IgG}_{\text {mix }}$ ) suppressed the growth of cancer cells more effectively than from human milk.

In summary, we have shown that polyclonal native IgG and sIgA from the same female's milk possess several enzymatic activities. The presence of the ABZ with different activities in the milk after childbirth may only be a part of the overall process of women's immune system restructuring. It is not yet clear what possible role ABZ with various activities can play in protecting mothers and infants from various harmful factors. However, it should be believed that the existence of such ABZ in human milk is not accidental. The sIgA Abs covering the mucous surfaces of newborns can possibly hydrolyze nucleic acids and proteins of harmful viruses and bacteria. Milk IgG, in contrast to $\operatorname{sg} \mathrm{A}$, can penetrate into the blood of neonates through the intestinal epithelium. Therefore, one cannot exclude the possibility that IgG can participate in the protection of the entire body of the newborn.

\section{CONCLUSIONS}

In this work, we carried out an analysis of the toxicity of IgG and sIgA Abs from the milk of healthy women in relation to fertilized eggs of sea urchins (embryotoxicity), the ability of sperm treated with Abs to fertilize eggs (sperm toxicity), and the effect of Abs on the growth of cancer cells. We showed that IgG and sIgA did not possess embryotoxicity. The sIgA decrease the ability of sperm to fertilize urchin eggs (1.6-fold) and suppress the growth of MCF-7 cancer cells (2.2fold) more efficiently than IgG Abs. The effect of IgG and sIgA on sperm and cancer cells correlate differently with their DNase, RNase, protease, amylase, and peroxidase catalytic activities.

\section{ACKNOWLEDGMENTS}

This study was granted by the Russian Foundation for Basic Research (No. 20-04-00281; Moscow, Russia) and from the Russian Foundation for Basic Research (No. 18-04-00442 $\mathrm{A}$; providing work with sea urchins, eggs, and sperm). The authors declare no conflicts of interest.

\section{REFERENCES}

Amino, N., H. Mori, and Y. Iwatani. 1986. High prevalence of transient post-partum thyrotoxicosis and hypothyroidism. New Engl. J. Med. 306:849-852. https://doi.org/10.1056/NEJM198204083061405.

Amino, N., H. Tada, and Y. Hidaka. 1999. Postpartum autoimmune thyroid syndrome: A model of aggravation of autoimmune disease. Thyroid 9:705-713.
Andrievskaya, O. A., V. N. Buneva, A. G. Baranovskii, A. V. Gal'vita, E. S. Benzo, V. A. Naumov, and G. A. Nevinsky. 2002. Catalytic diversity of polyclonal RNA-hydrolyzing IgG antibodies from the sera of patients with systemic lupus erythematosus. Immunol. Lett. 81:191-198. https://doi.org/10.1016/S0165-2478(02)00006-8.

Andrievskaya, O. A., V. N. Buneva, V. A. Naumov, and G. A. Nevinsky. 2000. Catalytic heterogenity of polyclonal RNA-hydrolyzing $\mathrm{IgM}$ from sera of patients with lupus erythematosus. Med. Sci. Monit. 6:460-470.

Andryushkova, A. A., I. A. Kuznetsova, I. A. Orlovskaya, V. N. Buneva, and G. A. Nevinsky. 2006. Antibodies with amylase activity from the sera of autoimmune-prone MRL/MpJ-lpr mice. FEBS Lett. 580:5089-5095. https://doi.org/10.1016/j.febslet.2006.08 .036 .

Andryushkova, A. A., I. A. Kuznetsova, I. A. Orlovskaya, V. N. Buneva, and G. A. Nevinsky. 2009. Nucleotide-hydrolyzing antibodies from the sera of autoimmune-prone MRL-lpr/lpr mice. Int. Immunol. 21:935-945. https://doi.org/10.1093/intimm/dxp060.

Andryushkova, A. A., I. A. Kuznetsova, V. N. Bineva, L. B. Toporkova, L. V. Sakhno, M. A. Tikhonova, E. R. Chernykh, I. A. Orlovskaya, and G. A. Nevinsky. 2007. Formation of different abzymes in autoimmune-prone MRL-lpr/lpr mice is associated with changes in colony formation of haematopoetic progenitors. J. Cell. Mol. Med. 11:531-551. https://doi.org/10.1111/j.1582-4934.2007.00048.x.

Aulova, K. S., L. B. Toporkova, J. A. Lopatnikova, A. A. Alshevskaya, S. E. Sedykh, V. N. Buneva, T. Budde, S. G. Meuth, N. A. Popova, I. A. Orlovskaya, and G. A. Nevinsky. 2018. Changes in cell differentiation and proliferation lead to production of abzymes in EAE mice treated with DNA-Histone complexes. J. Cell. Mol. Med. 22:5816-5832. https://doi.org/10.1111/jcmm.13850.

Aulova, K. S., L. B. Toporkova, J. A. Lopatnikova, A. A. Alshevskaya, S. V. Sennikov, V. N. Buneva, T. Budde, S. G. Meuth, N. A. Popova, I. A. Orlovskaya, and G. A. Nevinsky. 2017. Changes in haematopoietic progenitor colony differentiation and proliferation and the production of different abzymes in EAE mice treated with DNA. J. Cell. Mol. Med. 21:3795-3809. https://doi.org/10.1111/ jcmm.13289.

Aulova, K. S., A. E. Urusov, L. B. Toporkova, S. E. Sedykh, Y. A. Shevchenko, V. P. Tereshchenko, S. V. Sennikov, T. Budde, S. G. Meuth, N. A. Popova, and A. Irina. Orlovskaya, and G. A. Nevinsky. 2019. Production of Abzymes in Th, CBA, and C57BL/6 mice before and after MOG Treatment: Comparing Changes in Cell Differentiation and Proliferation. Biomolecules 10:53. https:/ /doi.org/10.3390/biom10010053.

Bezuglova, A. M., L. P. Konenkova, V. N. Buneva, and G. A. Nevinsky. 2012. IgG containing light chains of the $\lambda$ - and $\kappa$-type and of all subclasses ( $\operatorname{IgG} 1-\operatorname{Ig} G 4)$ from the sera of patients with systemic lupus erythematosus hydrolyze myelin basic protein. Int. Immunol. 24:759-770. https://doi.org/10.1093/intimm/dxs071.

Bezuglova, A. M., L. P. Konenkova, B. M. Doronin, V. N. Buneva, and G. A. Nevinsky. 2011. Affinity and catalytic heterogeneity and metal-dependence of polyclonal myelin basic protein-hydrolyzing IgG from sera of patients with systemic lupus erythematosus. J. Mol. Recognit. 24:960-974. https://doi.org/10.1002/jmr.1143.

Buneva, V. N., O. A. Andrievskaia, I. V. Romannikova, G. V. Gololobov, R. P. Iadav, V. I. Iamkovoi, and G. A. Nevinskii. 1994. Interaction of catalytically active antibodies with oligoribonucleotides. Mol. Biol. (Mosc.) 28:738-743.

Buneva, V. N., A. N. Kudryavtseva, A. V. Gal'vita, V. V. Dubrovskaya, O. V. Khokhlova, I. A. Kalinina, V. A. Galenok, and G. A. Nevinsky. 2003. Dynamics of antibody nuclease activity in blood of women during pregnancy and lactation. Biochemistry (Mosc.) 68:890-900. https://doi.org/10.1023/A:1025703132523.

Buznikov, G. A., and V. I. Podmarev. 1975. Objects of Developmental Biology. Nauka.

Coêlho, D. F., T. P. Saturnino, F. F. Fernandes, P. G. Mazzola, E. Silveira, and E. B. Tambourgi. 2016. Azocasein substrate for determination of proteolytic activity: Reexamining a traditional method using bromelain samples. BioMed Res. Int. 8409183. https://doi .org/10.1155/2016/8409183. 
Dayan, C. M., and G. H. Daniels. 1996. Chronic autoimmune thyroiditis. New Engl. J. Med. 335:99-107.

Doronin, V. B., T. A. Parkhomenko, A. Korablev, L. B. Toporkova, J. A. Lopatnikova, S. V. Alshevskaja, S. V. Sennikov, V. N. Buneva, T. Budde, S. G. Meuth, I. A. Orlovskaya, N. A. Popova, and G. A. Nevinsky. 2016. Changes in different parameters, lymphocyte proliferation and hematopoietic progenitor colony formation in EAE mice treated with myelin oligodendrocyte glycoprotein. J. Cell. Mol. Med. 20:81-94. https://doi.org/10.1111/jcmm.12704.

Fey, H., R. Butler, and F. Marti. 1973. The production in the pregnant cow of anti-human immunoglobulin to be used for the antiglobulin test. Vox Sang. 25:245-253. https://doi.org/10.1111/j.1423-0410 1973.tb04369.x

Fisher, B. M., J. E. Grilley, and R. T. Raines. 1998. A new remote subsite in ribonuclease A. J. Biol. Chem. 273:34134. https://doi .org/10.1074/jbc.273.51.34134.

Gorbunov, D. V., N. A. Karataeva, V. N. Buneva, and G. A. Nevinsky. 2005. Lipid kinase activity of antibodies from milk of clinically healthy human mothers. Biochim. Biophys. Acta 1735:153-166. https://doi.org/10.1016/j.bbalip.2005.06.007.

Gorbunov, D. V., D. V. Semenov, M. V. Shipitsin, Yu. Yu. Kit, T. G. Kanyshkova, V. N. Buneva, and G. A. Nevinsky. 2000. Phosphorylation of minor lipids of human milk tightly bound to secretory immunoglobulin A. Russ. J. Immunol. 5:267-278.

Hanson, L. A., B. Carlsson, and J. R. Cruz. 1979. T cell regulation of IgA synthesis. Pages 145-157 in Immunology of Breast Milk. P. L. Ogra and D. H. Dayton, ed. Raven Press.

Hanson, L. A., M. Hahn-Zoric, M. Berndes, R. Ashraf, V. Herias, F. Jalil, T. I. Bhutta, A. Laeeq, and I. Mattsby-Baltzer. 1994. Breast feeding: Overview and breast milk immunology. Acta Paediatr. Jpn. 36:557-561. https://doi.org/10.1111/j.1442-200X.1994 tb03246.x.

Irie, M., F. Mikami, K. Monma, K. Ohgi, H. Watanabe, R. Yamaguchi, and H. Nagase. 1984. Kinetic studies on the cleavage of oligouridilic acids and polyU by bovine pancreatic ribonuclease A. J. Biochem. 96:89-96. https://doi.org/10.1093/oxfordjournals .jbchem.a134833.

Jensen, R. G., J. Bitman, S. E. Carlson, S. C. Couch, M. Hamosh, and D. S. Newburg. 1995. Handbook of Milk Composition. Academic Press.

Kanyshkova, T. G., S. E. Babina, D. V. Semenov, N. Isaeva, A. V. Vlassov, K. N. Neustroev, A. A. Kul'minskaya, V. N. Buneva, and G. A. Nevinsky. 2003. Multiple enzymic activities of human milk lactoferrin. Eur. J. Biochem. 270:3353-3361. https://doi.org/10 $.1046 / \mathrm{j} .1432-1033.2003 .03715 . x$.

Karataeva, N. A., V. N. Buneva, and G. A. Nevinsky. 2006a. Polysaccharide kinase activity of human milk IgG antibodies. Biochemistry (Mosc.) 71:1207-1221. https://doi.org/10.1134/ S000629790611006X.

Karataeva, N. A., D. Gorbunov, I. V. Prokudin, V. N. Buneva, A. A. Kulminskaya, K. N. Neustroev, and G. A. Nevinsky. 2006b. Human milk antibodies with polysaccharide kinase activity. Immunol. Lett. 103:58-67. https://doi.org/10.1016/j.imlet.2005.10.009.

Kazakov, V. I., V. M. Bozhkov, V. A. Linde, M. A. Repina, and V. M. Mikhaillov. 1995. Extracellular DNA in the blood of pregnant women. Tsitologiia 37:232-236.

Keinan, E., ed. 2005. Catalytic Antibodies. Wiley-VCH Verlag GmbH and Co. KgaA.

Kit, YYa., D. V. Semenov, and G. A. Nevinsky. 1996. Phosphorylation of different human milk proteins by human catalytic secretory immunoglobulin A. Biochem. Mol. Biol. Int. 39:521-527. https://doi .org/10.1080/15216549600201571.

Kompaneets, I. Y., E. A. Ermakov, S. E. Sedykh, V. N. Buneva, and G. A. Nevinsky. 2020a. IgG from human milk hydrolyze microRNAs. Molecules 25:2366. https://doi.org/10.3390/molecules2510236.

Kompaneets, I. Y., E. A. Ermakov, S. E. Sedykh, V. N. Buneva, and G. A. Nevinsky. 2020b. Secretory immunoglobulin A from human milk hydrolyzes microRNA. J. Dairy Sci. 103:6782-6797. https:// doi.org/10.3168/jds.2019-17823.

Kozyr, A. V., A. V. Kolesnikov, E. S. Aleksandrova, L. P. Sashchenko, N. V. Gnuchev, P. V. Favorov, M. A. Kotelnikov, E. I. Iakhnina,
I. A. Astsaturov, T. B. Prokaeva, Z. S. Alekberova, S. V. Suchkov, and A. G. Gabibov. 1998. Novel functional activities of anti-DNA autoantibodies from sera of patients with lymphoproliferative and autoimmune diseases. Appl. Biochem. Biotechnol. 75:45-61. https: //doi.org/10.1007/BF02787708.

Krasnorutskii, M. A., V. N. Buneva, and G. A. Nevinsky. 2008. Antibodies against pancreatic ribonuclease A hydrolyze RNA and DNA. Int. Immunol. 20:1031-1040. https://doi.org/10.1093/ intimm/dxn061.

Krasnorutskii, M. A., V. N. Buneva, and G. A. Nevinsky. 2009. Immunization of rabbits with DNase II leads to formation of polyclonal antibodies with DNase and RNase activities. Int. Immunol. 21:349-360. https://doi.org/10.1093/intimm/dxp004.

Lönnerdal, B. 2003. Nutritional and physiologic significance of human milk proteins. Am. J. Clin. Nutr. 77(suppl):1537S-1543S. https:// doi.org/10.1301/nr.2003.sept.295-305.

Love, J. D., and R. R. Hewitt. 1979. The relationship between human serum and human pancreatic DNase I. J. Biol. Chem. 254:1258812594. https://doi.org/10.1016/S0021-9258(19)86355-X.

Mestecky, J., M. W. Russell, S. Jackson, and T. A. Brown. 1986. The human IgA system: A reassessment. Clin. Immunol. Immunopathol. 40:105-114. https://doi.org/10.1016/0090-1229(86)90073 -5 .

Mohan, C., S. Adams, V. Stanic, and S. K. Datta. 1993. Nucleosome: A major immunogen for pathogenic autoantibody-inducing $\mathrm{T}$ cells of lupus. J. Exp. Med. 177:1367-1381. https://doi.org/10.1084/ jem.177.5.1367.

Mosmann, T. 1983. Rapid colorimetric assay for cellular growth and survival: application to proliferation and cytotoxicity assays. J. Immunol. Methods 65:55-63. https://doi.org/10.1016/0022 -1759(83)90303-4.

Nevinsky, G. A. 2010. Natural catalytic antibodies in norm and in autoimmune diseases. Pages 1-107 in Autoimmune Diseases: Symptoms, Diagnosis and Treatment. K. J. Brenner, ed. Nova Science Publishers Inc.

Nevinsky, G. A. 2011. Natural catalytic antibodies in norm and in HIV-infected patients. Pages 151-192 in Understanding HIV/ AIDS Management and Care-Pandemic Approaches the 21st Century. F. H. Kasenga, ed. InTech.

Nevinsky, G. A. 2016. Autoimmune processes in multiple sclerosis: Production of harmful catalytic antibodies associated with significant changes in the hematopoietic stem cell differentiation and proliferation. Pages 100-147 in Multiple Sclerosis. A. ConzalezQuevedo, ed. InTech.

Nevinsky, G. A. 2017. Catalytic antibodies in norm and systemic lupus erythematosus. Pages 41-101 in Lupus. W. A. Khan, ed. InTech.

Nevinsky, G. A., and V. N. Buneva. 2003. Catalytic antibodies in healthy humans and patients with autoimmune and viral diseases. J. Cell. Mol. Med. 7:265-276. https://doi.org/10.1111/j.1582-4934 .2003.tb00227.x.

Nevinsky, G. A., and V. N. Buneva. 2005. Natural catalytic antibodies - abzymes. Pages 505-569 in Catalytic antibodies. E. Keinan, ed. VCH-Wiley Press.

Nevinsky, G. A., Y. Y. Kit, D. V. Semenov, D. Y. Khumankov, and V. N. Buneva. 1998. Secretory immunoglobulin A from human milk catalyses milk protein phosphorylation. Appl. Biochem. Biotechnol. 75:77-91. https://doi.org/10.1007/BF02787710.

Odintsova, E. S., V. N. Buneva, and G. A. Nevinsky. 2005. Caseinhydrolyzing activity of $\operatorname{sig} \mathrm{A}$ antibodies from human milk. J. Mol. Recognit. 18:413-421. https://doi.org/10.1002/jmr.743.

Paul, S. D., J. Volle, C. M. Beach, D. R. Johnson, M. J. Powell, and R. J. Massey. 1989. Catalytic hydrolysis of vasoactive intestinal peptide by human autoantibody. Science 244:1158-1162. https:// doi.org/10.1126/science.2727702.

Rechtman, D. J., B. Ferry, M. L. Lee, and H. Chapel. 2002. Immunoglobulin A ( $\operatorname{Ig} \mathrm{A})$ content of human breast milk over time. Int. J. Infect. Dis. 6(S3):S58. https://doi.org/10.1016/S1201 -9712(02)90302-4.

Savel'ev, A. N., E. V. Eneyskaya, K. A. Shabalin, V. Michael, M. V. Filatov, and K. N. Neustroev. 1999. Autoantibodies with amylolytic activity. Protein Pept. Lett. 6:179-184. 
Savel'ev, A. N., T. G. Kanyshkova, A. A. Kulminskaya, V. N. Buneva, E. V. Eneyskaya, M. V. Filatov, G. A. Nevinsky, and K. N. Neustroev. 2001. Amylolytic activity of IgG and $\operatorname{sgA}$ immunoglobulins from human milk. Clin. Chim. Acta 314:141-152. https://doi.org/ 10.1016/S0009-8981(01)00691-X.

Semenov, D. V., T. G. Kanyshkova, N. A. Karotaeva, M. A. Krasnorutskii, I. A. Kuznetsova, V. N. Buneva, and G. A. Nevinsky. 2004. Catalytic nucleotide-hydrolyzing antibodies in milk and serum of clinically healthy human mothers. Med. Sci. Monit. 10:BR23-BR33.

Sinohara, H., and K. Matsuura. 2000. Does catalytic activity of Bence Jones proteins contribute to the pathogenesis of multiple myeloma? Appl. Biochem. Biotechnol. 83:85-94. https://doi.org/10 $.1159 / 000058799$

Suck, D. 1994. DNA recognition by DNase I. J. Mol. Recognit. 7:6570. https://doi.org/10.1002/jmr.300070203.

Tolmacheva, A. S., V. N. Buneva, and G. A. Nevinsky. 2019. Substrate specificity of IgG with peroxidase and oxidoreductase activities from sera of patients with systemic lupus erythematosus and multiple sclerosis. J. Mol. Recognit. 32:e2807. https://doi.org/10 $.1002 / \mathrm{jmr} .2807$.

Tolmacheva, A. S., E. A. Ermakov, V. N. Buneva, and G. A. Nevinsky. 2018. Substrate specificity of healthy human sera IgG antibodies with peroxidase and oxydoreductase activities. R. Soc. Open Sci. 5:171097. https://doi.org/10.1098/rsos.171097.

Watanabe-Fukunaga, R., C. I. Brannan, N. G. Copeland, N. A. Jenkins, and S. Nagata. 1992. Lymphoproliferation disorder in mice explained by defects in Fas antigen that mediates apoptosis. Nature 356:314-317. https://doi.org/10.1038/356314a0.

Zakharova, O. D., T. S. Frolova, Y. V. Yushkova, E. I. Chernyak, A. G. Pokrovsky, M. A. Pokrovsky, S. V. Morozov, O. I. Sinitsina, I. A. Grigor'ev, and G. A. Nevinsky. 2016. Antioxidant and antitumor activity of Trolox, Trolox succinate, and $\alpha$-tocopheryl succinate conjugates with nitroxides. Eur. J. Med. Chem. 122:127-137. https://doi.org/10.1016/j.ejmech.2016.05.051.

\section{ORCIDS}

Georgy A. Nevinsky @i https://orcid.org/0000-0002-4988-8923 Ol'ga D. Zakharova (ํ) https://orcid.org/0000-0002-2054-561X Anna M. Timofeeva @ https://orcid.org/0000-0002-1270-7164 Pavel S. Dmitrenok @ https://orcid.org/0000-0002-8191-6170 Natalia I. Menzorova @ https://orcid.org/0000-0002-2616-7023 